\title{
REVIEW
}

\section{A review of studies on bioactive compounds isolated from Sri Lankan flora}

\author{
Asitha Siriwardhana ${ }^{1}$, Siril Wijesundara ${ }^{2}$ and Veranja Karunaratne $\mathrm{e}^{1,3^{*}}$ \\ ${ }^{2}$ Sri Lanka Institute of Nanotechnology, Nanotechnology and Science Park, Pitipana, Homagama. \\ ${ }^{2}$ Royal Botanic Gardens, Peradeniya. \\ ${ }^{3}$ Department of Chemistry, Faculty of Science, University of Peradeniya, Peradeniya.
}

Summary: The biodiversity of Sri Lanka based on the average number of plant species per $10,000 \mathrm{~km}^{2}$ has been stated to be much higher than in any other country in Asia. Despite the diversity and the potential economic value of these plants, many have not been investigated for their natural products. Also both the endemic and non-endemic plants species, which have been investigated chemically and biologically show a wide variety of bioactive compounds indicating the high economic potential of the flora. This paper reviews the studies of bioactve compounds isolated from Sri Lankan flora during the period 1980 to date.

Keywords: Biological activity, endemic plant species, medicinally important compounds, Sri Lankan flora.

\section{INTRODUCTION}

The World Conservation Monitoring Centre has designated Sri Lanka as a 'hotspot' in terms of its biodiversity (Caldecott et al., 1994). The indigenous flora of Sri Lanka comprises about 7,500 plant species. Of the recorded 3,154 flowering plant species, 894 (28\%) species are known to be endemic to the island (Wijesundara et al., 2012). There are also records of 336 species of pteridophytes, which include 49 endemics (MOE, 2012), 650 species of lichens belonging to the family Thelotremataceae (41 endemics), 575 mosses (endemism unknown), 303 liverworts (endemism unknown), 1920 species of fungi and some 900 species of algae (Somesekaram et al., 1997). The variety, richness and abundance of Sri Lankan flora and the high percentage of endemic plants - compared to most countries in the region - makes it an ideal location for a systematic drug discovery programme. The early botanical description of Sri Lankan plants is contained in a series of books (Trimen, 1885), which have been revised later (Dassanayake, 1996). Endemic plants in Sri Lanka are within easy access as more than $90 \%$ of them are located in a small area of about $15,000 \mathrm{~km}^{2}$ in the low country wet zone and the montane zone (Gunatilleke \& Gunatilleke, 1990).

A large number of plants with medicinal value has been listed in a compilation, the 'Sinhalese Materia Medica' (Attygala, 1917). Information on the chemistry and the pharmacology of some Sri Lankan and Indian plants (Chandrasena, 1935) and medicinal plants used in Sri Lanka (Jayaweera, 1982) is also documented.

During the past 40 years there have been several investigations on the chemical constituents and antimicrobial and insecticidal effects of Sri Lankan plants, particularly the endemics (Bandara et al., 1989a; 1989b; 1990b; Hewage et al., 1997; 1998). In addition the biological activity of compounds isolated from Sri Lankan lichens have also been determined (Nanayakkara et al., 2005). Tropical lichens, particularly those from Sri Lanka, continue to show a wide variety of biologically active compounds (Orange et al., 2001; Karunaratne et al., 2002; 2005; Jayalal et al., 2012). Antiradical and antilipoperoxidative effects of some plant extracts used by Sri Lankan traditional medical practitioners for cardioprotection has been reported by Munasinghe et al. (2001). Arseculeratne et al. (1985) have screened fifty medicinal plants for hepatotoxic activity. In a ground breaking study, the oral hypoglycaemic activity of some Sri Lankan plants have been reported by Karunanayake et al. (1984). The alkaloids found in 
Sri Lankan plants and their biological activities have been reviewed by Gunatilaka (1999).

However, in many of the early studies on bioactive compounds, the activity determinations were restricted to antibacterial and mosquito larvicidal activities, which are too broad to be useful determinants of high value bioactivities such as, antioxidant, insecticidal, $\alpha$-glucosidase, cytotoxic, enzyme inhibitory, spermicidal and anticancer activities. These compounds have become important and highly sought after. This review highlights the biological activity of compounds reported from endemic and non-endemic flora of Sri Lanka.

\section{Antioxidant activity}

Free radicals play an important role in carcinogenesis through their involvement in breaking the DNA strands. Free radicals also play a role in arteriosclerosis, malaria, in rheumatoid arthritis and could play a role in neurodegenerative diseases and the ageing process (Attaur-Rahman \& Choudhary, 2001).

Free radicals are unique bioactive mediators, which account for the tonic relaxation of all types of blood vessels and nonadrenergic and noncholinergic relaxation of the gastro intestinal tract in low concentration. At high concentrations they can damage DNA, RNA, lipids and proteins leading to increased mutations and altered enzymes, which in turn lead to carcinogenesis (Halici et al., 2005).

Xylopia championii Hook \& Thomas (Annonaceae) is endemic to Sri Lanka. Out of the five alkaloids isolated from stem bark and stem, (-)-discretine (Figure 1a) and (+)-laudanidine (Figure 1b), have shown a high antioxidant activity at a concentration of $0.5 \mathrm{mg} / \mathrm{mL}$, compared to the standard DL- $\alpha$-tocopherol in the DPPH assay (Puvanendran et al., 2008).

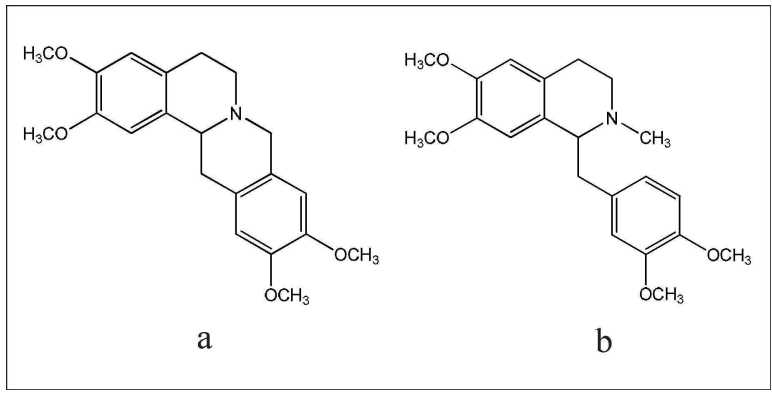

Figure 1: Structure of (a) (-)-discretine, (b) (+)-laudanidine
Chromatographic separation of the methanol extract of Elaeocarpus serratus L., leaves has afforded 3-O-Lrhamnopyranosyl-5,7-dihydroxy-2-(3,4,5-trihydroxyphenyl)-chromen-4-one (myricitrin) (Figure 2). The antioxidant activity of this compound has been evaluated by the DPPH radical-TLC bio-autography method where it has shown strong off-white spot on the TLC plate at $0.1 \mu \mathrm{g} / \mathrm{spot}$ indicating antioxidant activity comparable to standard ascorbic acid $\left(\mathrm{IC}_{50}=3.9 \mu \mathrm{g} / \mathrm{mL}\right)$ and butylated hydroxylanisole $\left(\mathrm{IC}_{50}=3.6 \mu \mathrm{g} / \mathrm{mL}\right.$ ) (Jayasinghe et al., 2012).

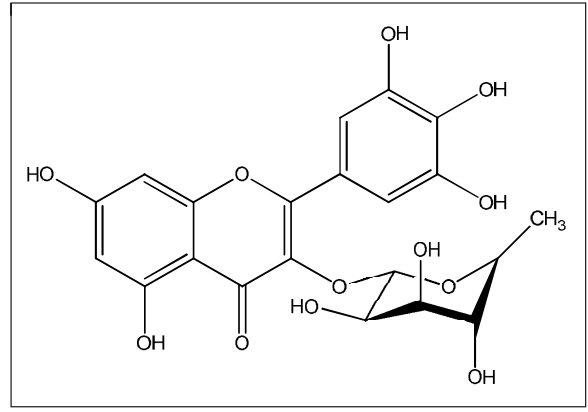

Figure 2: Structure of myricitrin

The two stilbene derivatives, (E)-4-isopentenyl3,5,20,40-tetrahydroxystilbene (Figure 3a) and (E)-4(3-methyl-E-but-1-enyl)-3,5,20,40-tetrahydroxystilbene (Figure $3 b$ ) isolated from the methanol extract of the stem bark of Artocarpus nobilis Thwaites have shown a significant antioxidant activity towards the DPPH radical in the TLC bio-autography method at $1 \mu \mathrm{g} / \mathrm{spot}$ (Jayasinghe et al., 2004).

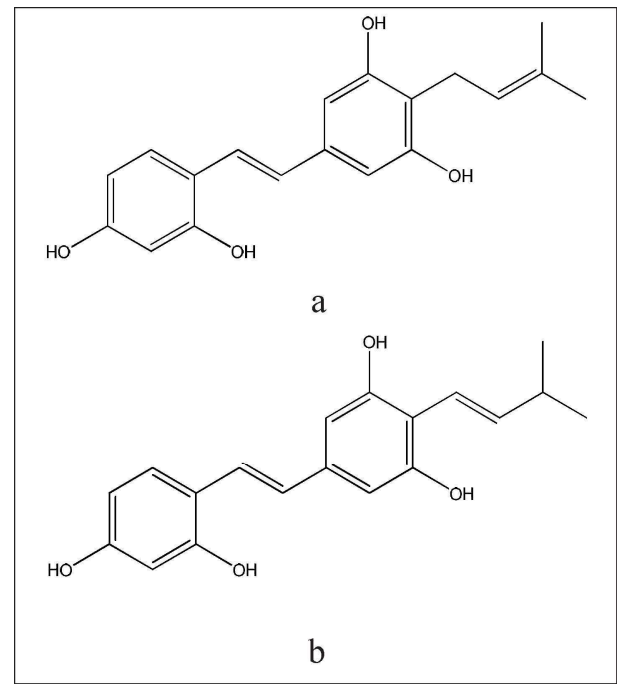

Figure 3: Structure of (a) (E)-4-isopentenyl-3,5,20,40-tetrahydroxystilbene and (b) (E)-4-(3-methyl-E-but-1-enyl)-3,5,20,40tetrahydroxystilbene 
Chemical investigation of the dichloromethane extract of the leaves of Syzygium jambos L., have resulted in three dihydrochalcones, phloretin (4'-O-methyl ether (2',6'-dihydroxy-4'-methoxydihydrochalcone) (Figure 4a), myrigalone G (2',6'-dihydroxy-4'methoxy-3'-methyldihydrochalcone) (Figure 4b), and myrigalone B (2',6'-dihydroxy-4'-methoxy-3,5'dimethyldihydrochalcone) (Figure 4c) with radical scavenging properties towards the DPPH radical (Jayasinghe et al., 2007).

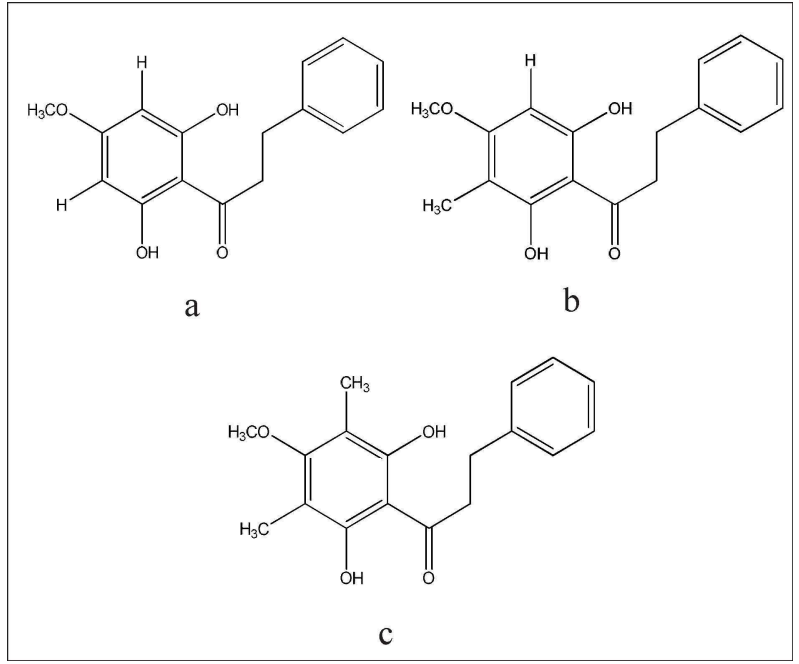

Figure 4: Structure of (a) phloretin; (b) myrigalone $G$ and (c) myrigalone $\mathrm{B}$

Among the three compounds isolated, myrigalone $\mathrm{B}$ has exhibited the highest free radical scavenging activity with an $\mathrm{IC}_{50}$ value of $3.8 \mu \mathrm{g} / \mathrm{mL}$ compared with that of the standard DL $\alpha$-tocopherol $\left(\mathrm{IC}_{50}=7.3 \mu \mathrm{g} / \mathrm{mL}\right)$. Myrigalone $\mathrm{G}$ has shown moderate free radical scavenging activity $\left(\mathrm{IC}_{50}=10.6 \mu \mathrm{g} / \mathrm{mL}\right)$, while phloretin has exhibited low antioxidant activity $\left(\mathrm{IC}_{50}=30 \mu \mathrm{g} / \mathrm{mL}\right)$ compared to that of DL $\alpha$-tocopherol (Jayasinghe et al., 2007).

\section{Insecticidal activity}

From the early Roman times to the mid $20^{\text {th }}$ Century pyrethrum, rotenone, nicotine, sabadilla and quassin have been used widely as insect repellents and toxins. The indiscriminate use of synthetic insecticidal compounds has led to deterioration of the environment and they also induce the build up of resistant pest populations, eliminate their natural enemies and facilitate the resultant development of secondary pests. Plants contain a wide diversity of secondary metabolites, some of which play an important role in their defense against pathogens and herbivores (Ware \& Whitaker, 2004). Botanicals used as insecticides presently constitute $1 \%$ of the world insecticide market (Rozman et al., 2007).

Pyxine consocians is a lichen growing on the stem bark of the palm tree Roystonia regia. The hexane extract of $P$. consocians has led to the isolation of three mosquito larvicidal compounds against Aedes aegypti at $10 \mathrm{ppm}$ : cabraleadiol monoacetate (Figure 5a) (90\% moribund after $24 \mathrm{~h}$ ), 4-O-methylcryptochlorophaeic acid (Figure 5 b) (60\% dead after $24 \mathrm{~h}$ ) and lichexanthone (Figure 5c) (80 \% moribund after $24 \mathrm{~h}$ ) (Kathirgamanathar et al., 2006).

The investigation of biologically active constituents of Heterodermia leucomelos, a lichen collected from the mossy rocks in the Horton Plains National Park, Nuwara Eliya District, Sri lanka, has led to the isolation of mosquito larvicidal active compound, 3,6-dimethyl-

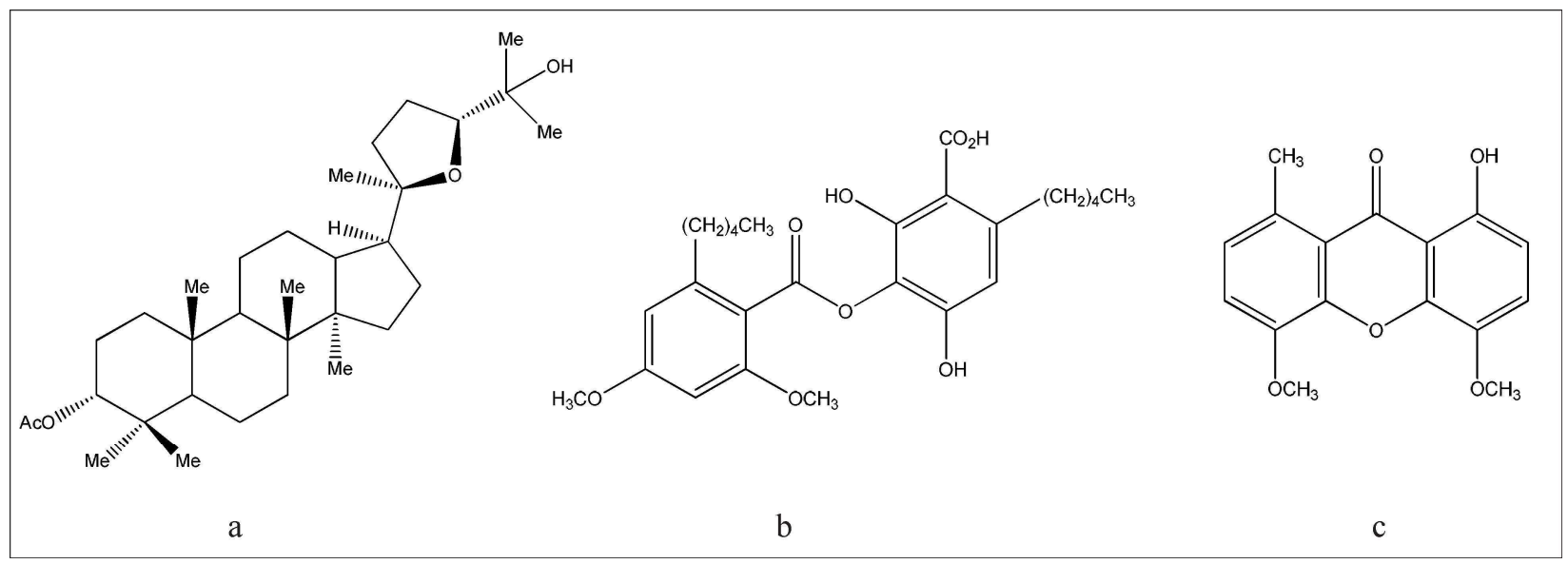

Figure 5: Structure of (a) cabraleadiolmonoacetate; (b) 4-O-methylcryptochlorophaeic acid and (c) lichexanthone 
2-hydroxy-4-methoxybenzoic acid (Figure 6) (90 \% moribund after $24 \mathrm{~h}$ at $10 \mathrm{ppm}$ ) (Kathirgamanathar et al., 2006). Hydroxy benzoic acids are important iron chelators (siderophores), which are secreted by some pathogenic bacteria that grow under low iron conditions (Feistner \& Beaman, 1987; Karunaratne et al., 1992). It is known that polar lichen substances are secreted out into the growing medium of the lichens, leading to the intriguing hypothesis that such bioactivities may form part of the chemical defense mechanisms of lichens (Karunaratne et al., 2005).

The two butenolides (Figure 7a) and (Figure 7b) isolated from the $\mathrm{CH}_{2} \mathrm{Cl}_{2}$ extracts of three representative species of the endemic genus Hortonia, H. floribunda, $H$. angustifolia and $H$. ovalifolia have exhibited potent mosquito larvicidal activity against the $2^{\text {nd }}$ instar larvae of $A$. aegypti with $\mathrm{IC}_{50}$ values of 0.41 and $0.47 \mathrm{ppm}$, respectively, highlighting the importance and the potency of five membered ring compounds (Ratnayake et al., 2001; Piers \& Karunaratne, 1983).

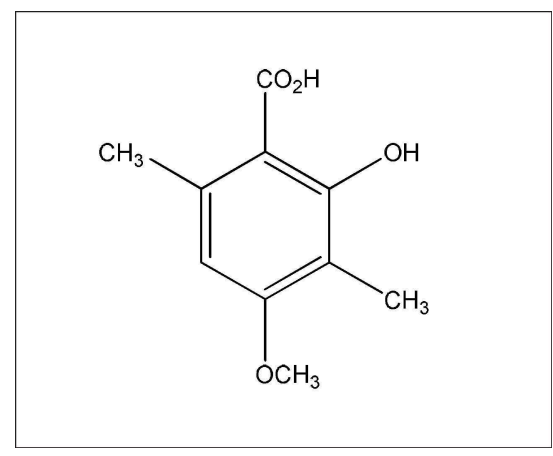

Figure 6: Structure of 3,6-dimethyl-2-hydroxy -4-methoxybenzoic acid

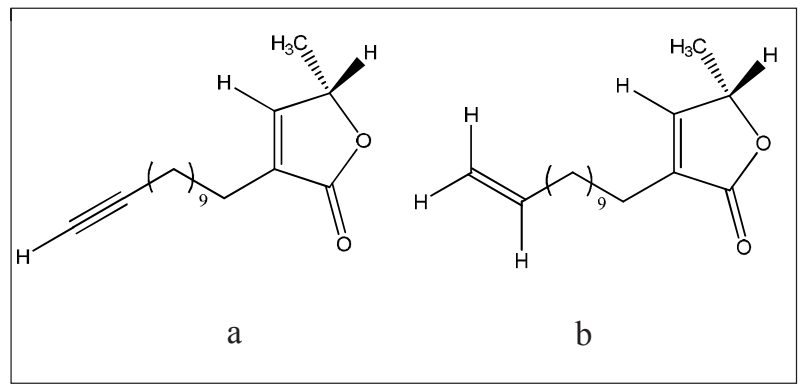

Figure 7: Structure of two butenolides [(a) and (b)] from genus Hortonia

Activity guided isolation from the combined methanol and dichloromethane extracts of the stem bark of Microcos paniculata L., has provided an insecticidal

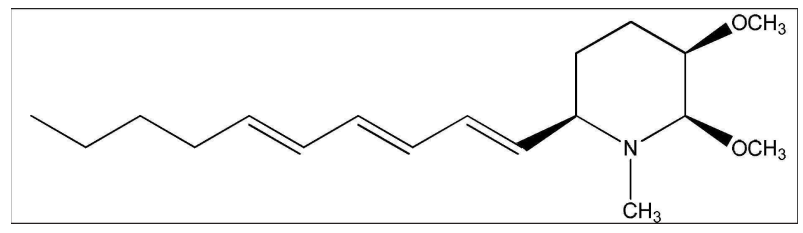

Figure 8: Structure of n-methyl-6b-(decal-3',5'-trienyl)-3b-methoxy2b-methylpiperidine

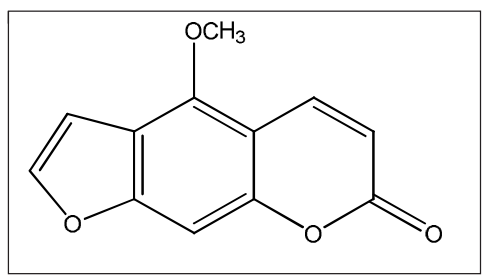

Figure 9: Structure of bergapten

alkaloid, N-methyl-6b-(decal-3',5'-trienyl)-3b-methoxy2b-methylpiperidine (Figure 8), which exhibited $\mathrm{MC}_{50}$ of $1.0 \mathrm{ppm}$ and $\mathrm{LC}_{50}$ of $2.1 \mathrm{ppm}$ at $24 \mathrm{~h}$ against $A$. aegypti second instar larvae. The $\mathrm{MC}_{50}$ and $\mathrm{LC}_{50}$ of the compound at 24, 48 and $72 \mathrm{~h}$ has indicated that a very few of the moribund larvae survived, most dying after about $72 \mathrm{~h}$ after treatment (Bandara et al., 2000).

Bergapten (Figure 9) isolated from the stem bark of Limonia acidissima L., (Rutaceae), a medicinal plant widely distributed in Sri Lanka has tested positive for insecticidal activity against Callosobruchus chinensis L. Bergapten has reduced the emergence of adults by $100 \%$ at $0.1 \mathrm{mg}$ level (Bandara et al., 1989b; 1990b).

The shot-hole borer, Xyleborus fornicatus Eichh., is a small, wood boring ambrosia beetle and is considered to be the most serious pest of Tea (Camellia sinensis var. assimica) in Sri Lanka. (+)-Usnic acid (Figure 10) has been isolated from an Usnea sp. collected from the surface of a rotting Acacia decurrens Willd., tree in Ambewela, Nuwara Eliya District, Sri Lanka. Healthy adult females of $X$. fornicatus exposed to different

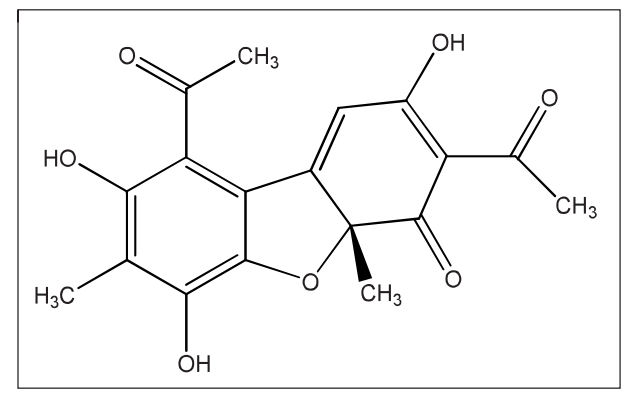

Figure 10: Structure of (+)-usnic acid 
concentrations of $(+)$-usnic acid have shown an effect on the growth development of beetles. At 75 and 100 ppm, only 10 and 4 mother beetles have produced progeny, respectively. The galleries constructed in the test media containing $(+)$-usnic acid have been observed to be of an irregular shape compared to the control (Sahib et al., 2008).

Along with (+)-usnic acid, two $\beta$-orcinol depsidone lactones, the methyl ethers of menegazziaic acid and stictic acid were isolated, in addition to glyceryl trilinolate. Usnic acid has exhibited potent antitermite activity against a common tea pest, Glyptotermes dilatatus at low elevations (Kathirgamanathar et al., 2005).

The hot petrol extracts of the roots of Croton lacciferus L., has shown significant insecticidal activity against Aphis cracciuora Koch. The extract, when chromatographed over silica gel and eluted with petrol-chloroform has yielded three ent-kauranoids, two of which are new natural products. The two new kauranoids (Figure 11a \& b) have been tested using the microapplicator method for insecticidal activity against A. cracciuora maintained in the laboratory on one-weekold potted cowpea, Vigna unguiculata L. These two compounds have shown a moderate insecticidal activity against $A$. craccivora at a dose of 5 ppm/insect causing 61 and $62 \%$ mortality, respectively, of adult female aphids after $24 \mathrm{~h}$ (Bandara et al., 1988a).

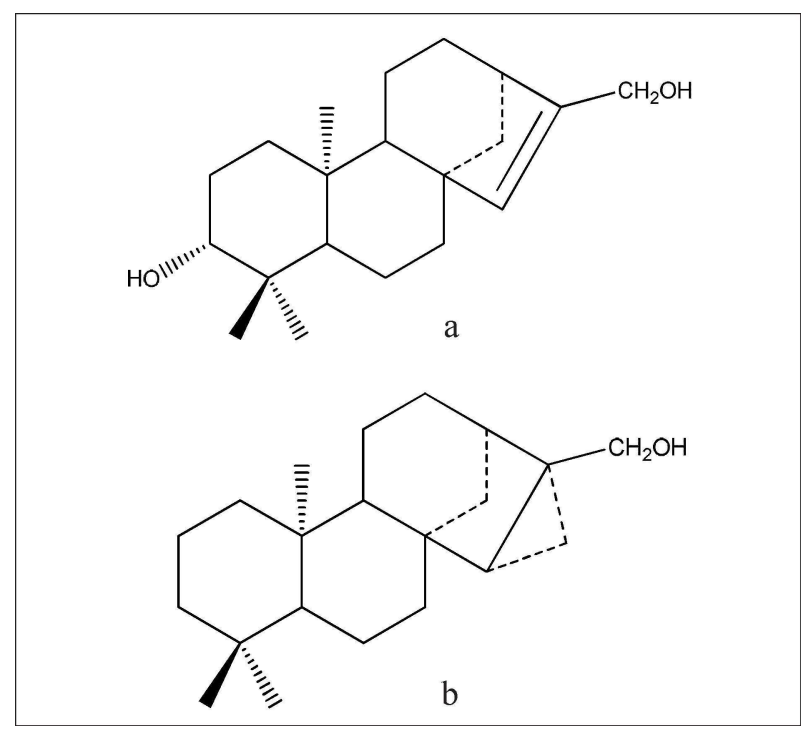

Figure 11: Structure of two new kauranoids [(a) and (b)] from Croton lacciferus $\mathrm{L}$.
Diploclisia glaucescens (Blume) Diels (Memspermaceae) is a creeper growing in the mid-country regions of South India and Sri Lanka. Ecdysterone (Figure 12) along with a bidesmosidic triterpenoid saponin have been isolated from the methanol extract of the stem of $D$. glaucescens in a yield of over $0.46 \%$. It possessed insecticidal activity against groundnut aphid, Aphis craccivora with an $\mathrm{LD}_{50}$ value of $18 \mathrm{mg} / \mathrm{kg}$ (Bandara et al., 1989c; d).

Croton aromaticus L., (Euphorbiaceae), a widely distributed plant in Sri Lanka, is used in ethnomedical preparations and in traditional agriculture. The air-dried and powdered roots of $C$. aromaticus have been subjected to sequential solvent extraction. The petroleum ether extract was chromatographed over silica gel when (-)hardwickiic acid (Figure 13) was isolated in $0.8 \%$. The aphidicidal activity of the compound has been evaluated using the microapplicator method. The compound at a dose of $5 \mathrm{ppm} /$ insect has caused $62 \%$ mortality of adult female aphids after $24 \mathrm{~h}$ (Bandara et al., 1987).

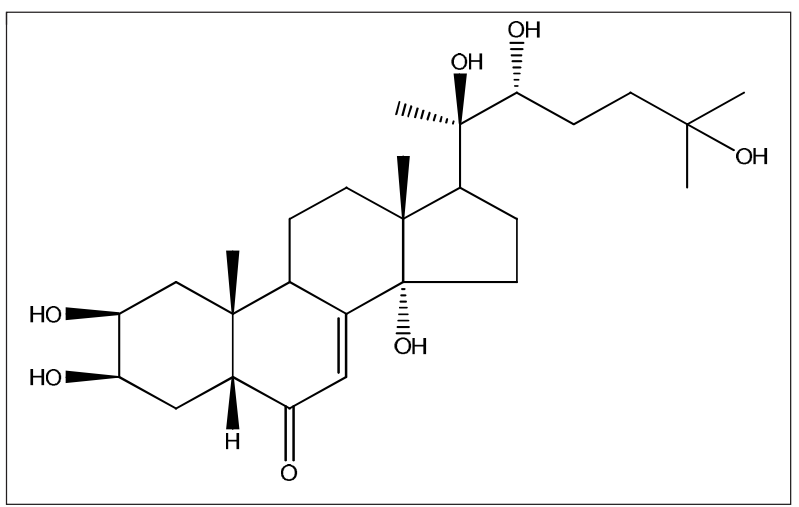

Figure 12: Structure of ecdysterone

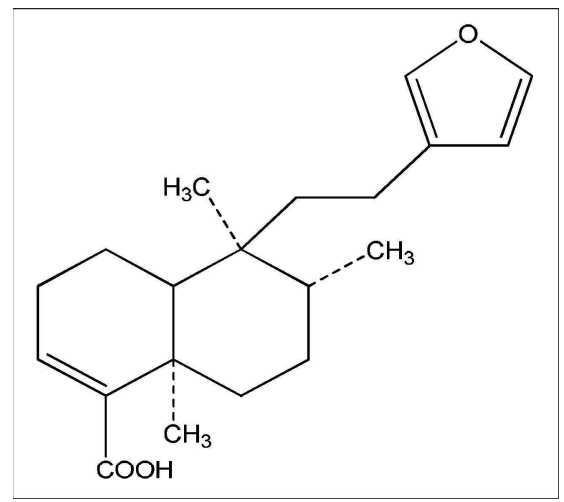

Figure 13: Structure of (-)-hardwickiic acid 


\section{Antibacterial activity}

The search for new antibiotics with hitherto unknown modes of action remains an urgent priority as microbial resistance to antimicrobial agents continues to unfold as one of the most difficult problems facing the physicians dealing with infectious diseases (Ristuccia \& Cunha, 1984). Bacteria are capable of passing genetic information between species through a process called conjugation. This property and the relatively short generation time have been important and led to the current situation in which the control of pathogenic bacteria has been difficult. In 1961, outbreaks of methicillin resistant Staphyloccocus aureus (MRSA) were sporadic and the introduction of new antibiotics kept the bacteria at bay. Since then, MRSA has acquired resistance to virtually all antibiotics in clinical use including cephalosporins, tetracyclines, aminoglycosides, erythromycin and the sulfonamides (Neu, 1992).

Four lichen species, Parmotrema grayana Hue, Cladonia sp., Heterodermia obscurata (Nyl.), and Roccella montagnei Bel, collected from different locations in Sri Lanka have been investigated: P. grayana from the stem bark of palm tree [Roystonea regia (Kunth) O.F. Cook (syn. $R$. elata, $R$. floridana)]; Cladonia sp., from rocks in the Labukelle region, Central Province; $H$. obscurata from the rocks in the Beragala region, Central Province and $R$. montagnei from coconut

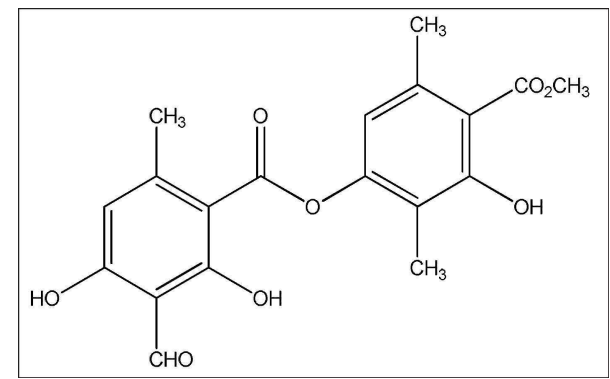

Figure 14: Structure of atranorin

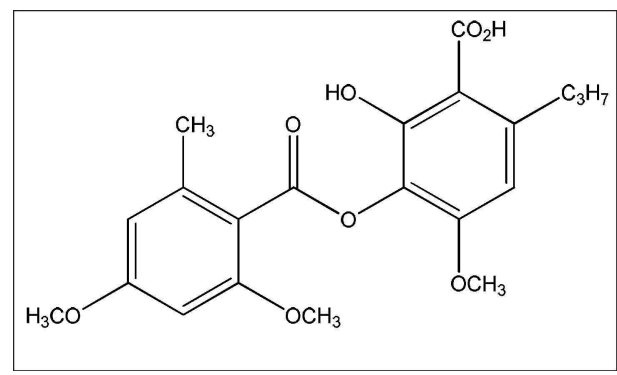

Figure 15: Structure of sekikaic acid palm trees (Cocos nucifera L.). Atranorin (Figure 14) isolated from all four lichen species has exhibited a moderate antibacterial activity against Escherichia coli, Bacillus subtilis and Salmonella typhi at a concentration of $100 \mu \mathrm{g} / \mathrm{mL}$ in the agar well diffusion method with inhibition zones of 13,12 and $12 \mathrm{~mm}$, respectively.

Sekikaic acid (Figure 15) isolated from H. obscurata has shown a moderate antibacterial activity against $E$.coli, B. subtilis and S. typhi at a concentration of $100 \mu \mathrm{g} / \mathrm{mL}$ in agar well diffusion method with an inhibition zone of $16 \mathrm{~mm}$.

Methanolyis of lecanoric acid isolated from Cladonia sp., H. obscurata and P. grayana, has yielded the mononuclear aromatic compound methyl orsellinate (Figure 16), which exhibited a moderate antibacterial activity against $E$. coli, B. subtillus and S. typhi (Thadani et al., 2012).

The methanol extract of the brown seaweed, Stoechospermum marginatum C. Agardh, grown in seas around the Northern part of Sri Lanka has been found to inhibit the growth of Staphylococcus aureus in the standard disk method. Fractionation of the active extract has led to the isolation of an antibacterial compound whose structure has been established to be 19-acetoxy5,15,18-trihydroxyspata-13,16-diene (Figure 17) (De Silva et al., 1982).

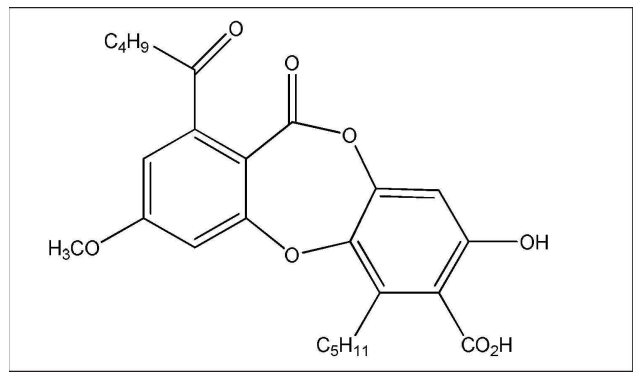

Figure 16: Structure of methyl orsellinate

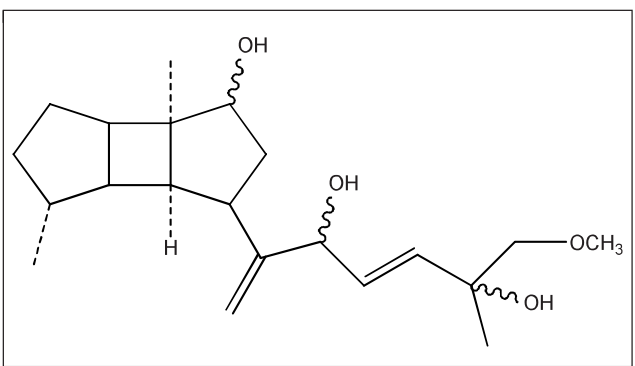

Figure 17: Structure of 19-acetoxy-5,15,18trihydroxyspata-13,16-diene 


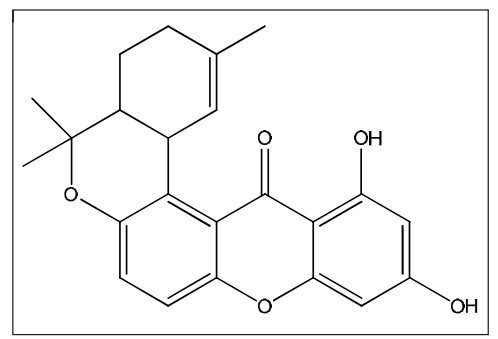

Figure 18: Structure of calozeyloxanthone

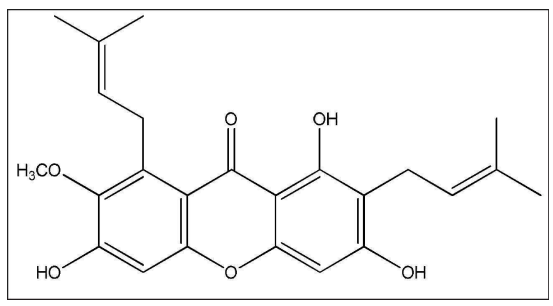

Figure 19: Structure of $\alpha$-mangostin

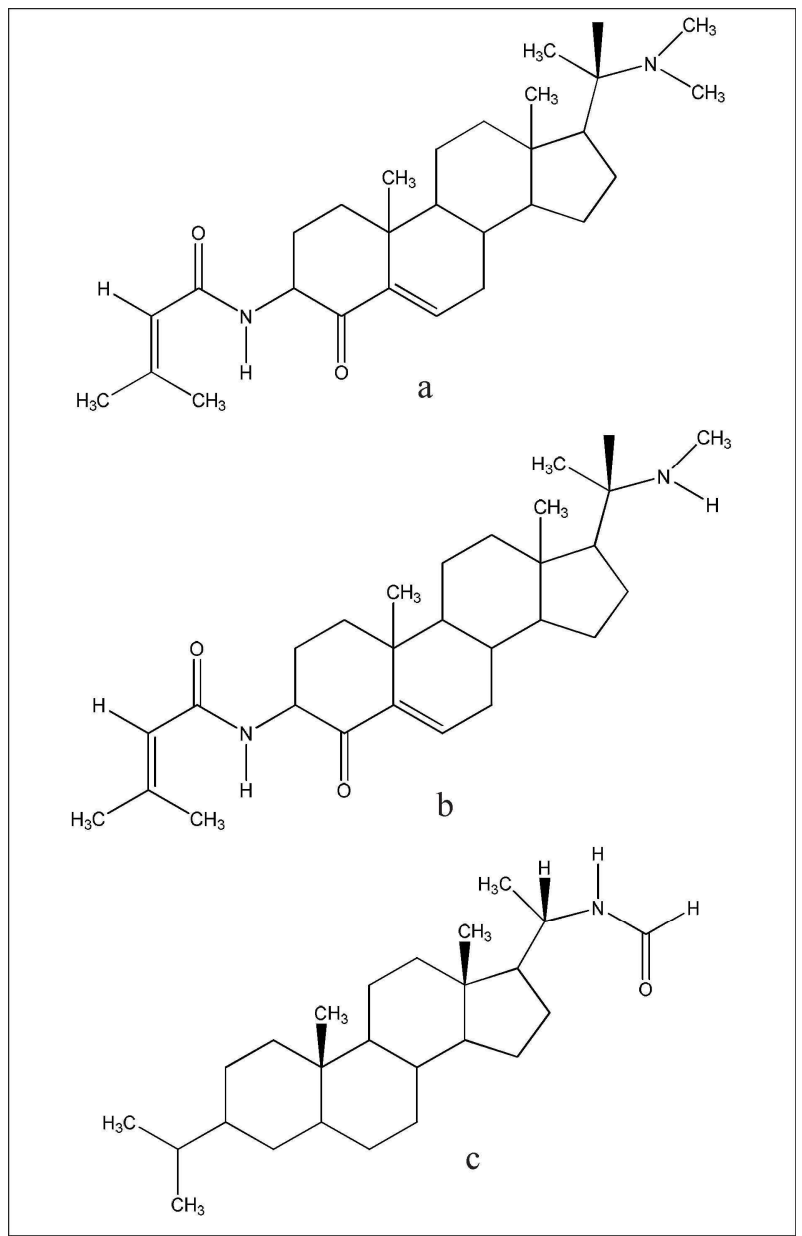

Figure 20: Structure of (a) epipachysamine-E-5-ene-4-on; (b) $\mathrm{N}_{\mathrm{b}}$ demethylepipachysamine-E-5-ene-4-on and (c) iso-Nformylchonemorphin
Calozeyloxanthone (Figure 18), isolated from Calophyllum thwaitesii Planchon \& Triana and C. moonii Wight, has shown a significant antibacterial activity againstmethicillin-resistantStaphylococcus aureus giving a MIC value of $4.1-8.1 \mu \mathrm{g} / \mathrm{mL}$, which is comparable with that of standard compounds, vancomycin $(\mathrm{MIC}=$ $0.5-4 \mu \mathrm{g} / \mathrm{mL}$ ) and gentamycin ( $\mathrm{MIC}=0.5-1 \mu \mathrm{g} / \mathrm{mL}$ ) (Dharmaratne et al., 1999).

$\alpha$-Mangostin (Figure 19), isolated from the stem bark of Garcinia mangostana L., has been found to be active against vancomycin resistant Enterococci (VRE) and methicillin resistant Staphylococcus aureus (MRSA) with MIC values of 6.25 and 6.25 to $12.5 \mu \mathrm{g} / \mathrm{mL}$, respectively. Further, synergism between $\alpha$-mangostin and gentamicin (GM) against VRE, and $\alpha$-mangostin and vancomycin hydrochloride (VCM) against MRSA has been observed. Moreover, partial synergism between $\alpha$-mangostin and commercially available antibiotics such as ampicillin and minocycline has also been discovered.

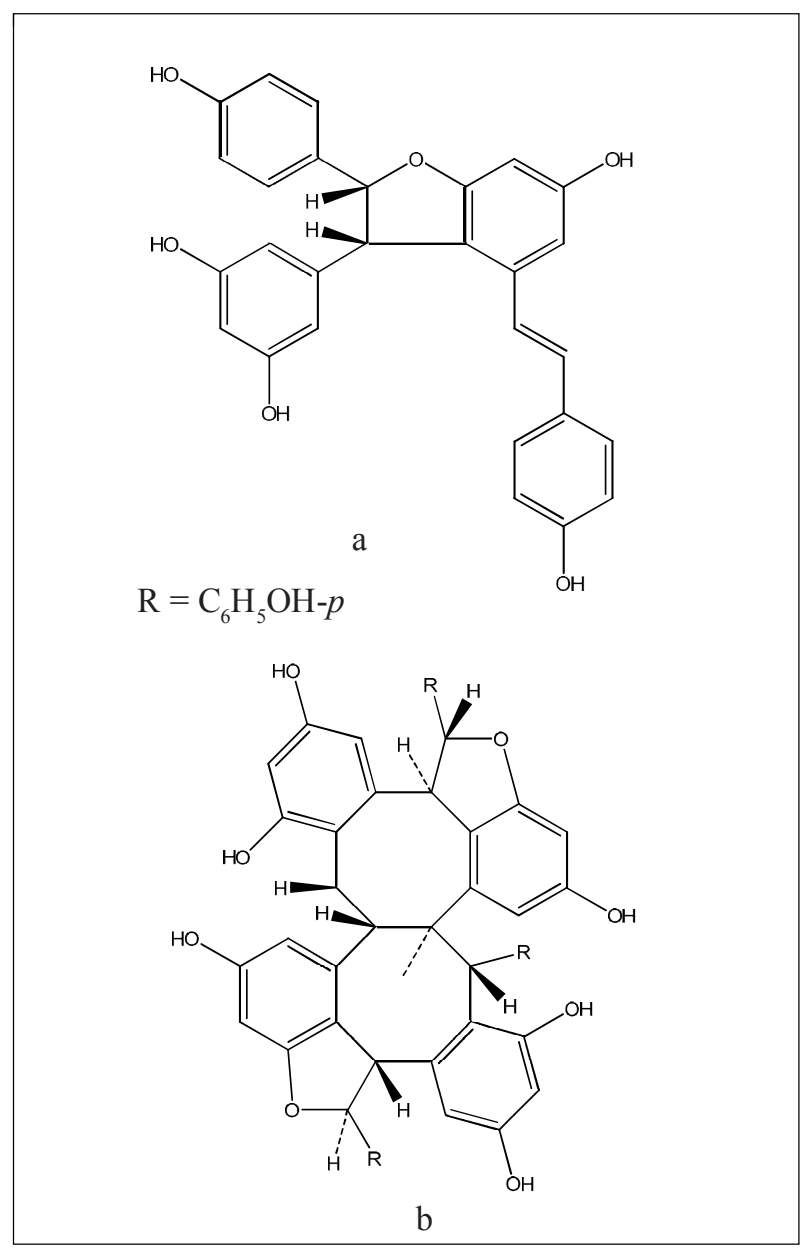

Figure 21: Structure of (a) $\varepsilon$-viniferin and (b) vaticaffinol 
These findings suggested that $\alpha$-mangostin alone or in combination with GM against VRE and in combination with VCM against MRSA might be useful in controlling VRE and MRSA infections (Sakagami et al., 2005).

The dried whole plant of Sarcococca brevifolia Muell., extracted with methanol and separated on silica gel yielded three steroidal alkaloids; epipachysamine-E-5-ene-4-on (Figure 20a), $\mathrm{N}_{\mathrm{b}}$-demethylepipachysamine-E-5-ene-4on (Figure 20b) and iso-N-formylchonemorphin (Figure 20c). The evaluation of antibacterial activity by agar well diffusion method has indicated that epipachysamineE-5-ene-4-on and iso-N-formylchonemorphin exhibit strong activity against a number of pathogenic bacteria. Antibacterial activity of epipachysamine-E-5-ene-4-on has been observed against Bacillus cereus ( $\mathrm{MIC}=0.0625$ $\mathrm{mg} / \mathrm{mL}$ ), Klebsiella pneumoniae ( $\mathrm{MIC}=0.25 \mathrm{mg} / \mathrm{mL}$ ) and Staphylococcus aureus (MIC $=0.03125 \mathrm{mg} / \mathrm{mL}$ ). Similarly, iso-N-formylchonemorphin has shown antibacterial strong activity against Bacillus cereus (MIC $=0.1250 \mathrm{mg} / \mathrm{mL})$, Pseudomonas aeruginosa $(\mathrm{MIC}=$ $0.1250 \mathrm{mg} / \mathrm{mL}$ ) and Staphylococcus aureus (MIC = $0.0312 \mathrm{mg} / \mathrm{mL}$ ) (Jayasinghe et al., 1998).

Vatica affinis Thw., is a dipterocarp species endemic to Sri Lanka. The cold acetone extracts of the bark and timber of this species have been chemically investigated and a resveratrol dimer, $\varepsilon$ - viniferin (Figure 21a), has been isolated from the extract by using silica gel preparative plates. A silica column chromatography of the extract

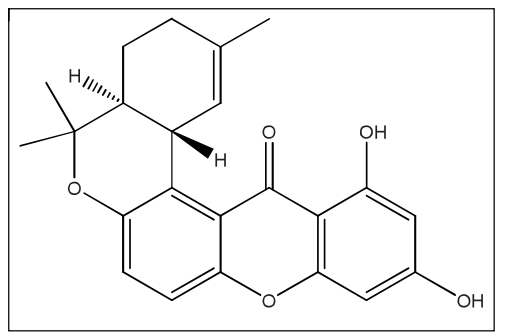

Figure 22: Structure of calozeyloxanthone

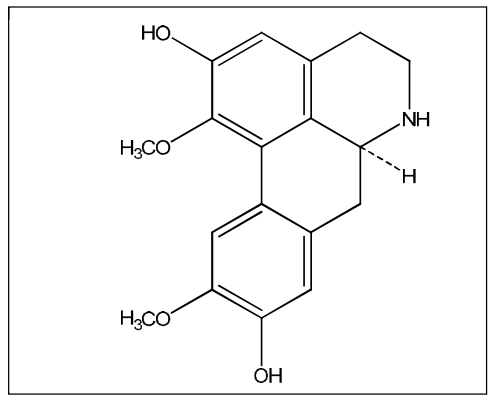

Figure 23: Structure of laurolitsine has yielded a second compound vaticaffinol (Figure $21 b)$, when the column was eluted with acetone-benzene (7:13). Both $\varepsilon$-viniferin and vaticaffinol isolated in this study has shown antibacterial activity towards Oxford Staphylococcus and Escherichia coli when tested by the filter paper disc method in Mueller Hinton Agar medium (Sotheeswaran et al., 1985).

Calophyllum moonii Wight., is an endemic species to Sri Lanka. Calozeyloxanthone (Figure 22) has been re-isolated from the root bark of C. moonii and was tested for antibacterial activity against vancomycinresistant Enterococci (VRE) and vancomycin-sensitive Enterococci (VSE). Results of the study has indicated that calozeyloxanthone is strongly active against both tested species with MIC values of 6.25 and $12.5 \mu \mathrm{g} / \mathrm{mL}$, respectively. Further, a marked synergism between calozeyloxanthone and vancomycin hydrochloride (VCM) against VRE has been observed (Sakagami et al., 2002).

Litsea gardneri L., is a moderate sized endemic plant in Sri Lanka. Alkaloids extracted from the defatted bark of $L$. gardneni have been tested for antibacterial activity against $E$. coli and $S$. aureus using the modified tube dilution technique. Four alkaloids have been isolated and the activity was observed only for laurolitsine (Figure 23) (against $S$. aureus), the minimum inhibitory concentration being $250 \mu \mathrm{g} / \mathrm{mL}$ (Bandara et al., 1989e).

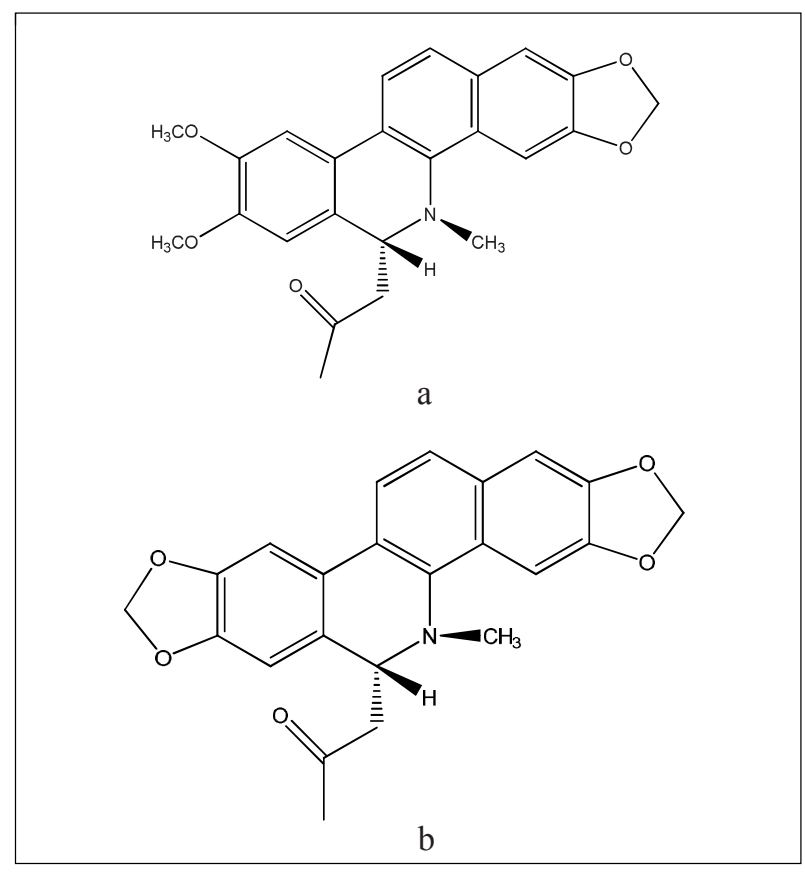

Figure 24: Structure of (a) 8-acetonyldihydronitidine and (b) 8-acetonyldihydroavicine 
Two benzophenanthrene alkaloids, 8-acetonyldihydronitidine (Figure 24a) and 8-acetonyldihydroavicine (Figure 24 b) have been isolated from Zanthoxylum tetraspermum Wight., stem bark along with liriodenine, sesamin, lichexanthone and (+)-piperitol- $\gamma, \gamma$ dimethylallylether. The Zanthoxylum species endemic to Sri Lanka, Z. caudatum, contains sesamin, savinin, liriodenine, decarine and 8-O-desmethyl-N-nornitidine. 8-Acetonyldihydronitidine and 8-acetonyldihydroavicine has shown significant growth inhibition of $S$. aureus (MIC value $=1.56$ and $3.12 \mu \mathrm{g} / \mathrm{mL}$, respectively). Furthermore, 8-acetonyldihydronitidine has exhibited strong antifungal activity against $C$. cladosporioides (area of inhibition $100 \mathrm{~mm}^{2}$ at $2 \mathrm{mg}$ ) (Nissanka et al., 2001).

\section{Antifungal activity}

Synthetic fungicides are currently used as the primary means for the control of plant disease.

However, alternative control methods are needed due to the negative public perceptions regarding the use of synthetic chemicals such as resistance to fungicides among fungal pathogens, and the high development cost of new chemicals. The use of plant-derived products as disease control agents have been studied, since they tend to have a low mammalian toxicity, less environmental effects and wide public acceptance (Lee et al., 2007). Preventing fungal decay in organic fruits after harvest is an increasing challenge, and novel preservation approaches, which comply with organic food standards need to be developed.

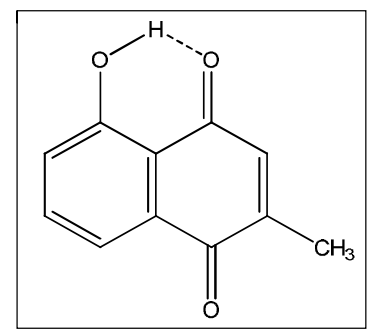

Figure 25: Structure of plumbagin

Plumbagin (Figure 25) is one of the bioactive metabolites found in Plumbago zeylanica L., P. indica and $P$. europaea. The antifungal activity of plumbagin against Cladosporium cladosporioides, Alternaria tunis, Botrydiplodia theobromae, Aspergillus sp., Fusarium sp., Cercospora nicotinae, and two isolates of Colletotrichum gloeosporioides obtained from avocado

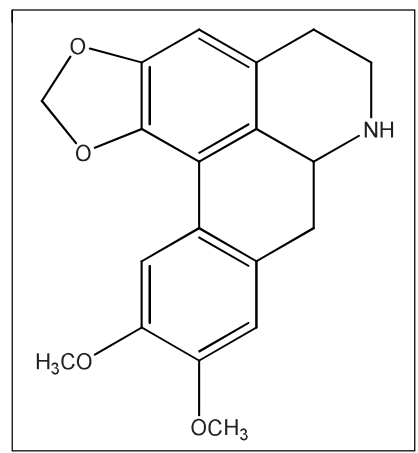

Figure 26: Structure of nordicentrine

and papaya has been determined using thin layer chromatography (TLC) bioassay. Plumbagin has shown higher antifungal activities against $A$. tunis (inhibition area $=4.5 \mathrm{~cm}^{2}$ ), B. theobromae (inhibition area $=$ $0.8 \mathrm{~cm}^{2}$ ), Fusarium sp. (Inhibition area $=2.5 \mathrm{~cm}^{2}$ ), and C. gloeosporioides (Inhibition area $=4.5 \mathrm{~cm}^{2}$ ) compared to that of standard antifungal agent benlate (Adikaram et al., 2002). On a spore germination assay conducted against $C$. gloeosporioides, a plumbagin solution at and above $31 \mu \mathrm{g} / \mathrm{mL}$ has caused total inhibition with an $\mathrm{IC}_{50}$ value of $6.86 \mu \mathrm{g} / \mathrm{mL}$, whereas at $50 \mu \mathrm{g} / \mathrm{mL}$ of the standard benlate required for the total inhibition $\left(\mathrm{IC}_{50}=\right.$ $44 \mu \mathrm{g} / \mathrm{mL}$ ) (Adikaram et al., 2002) was higher.

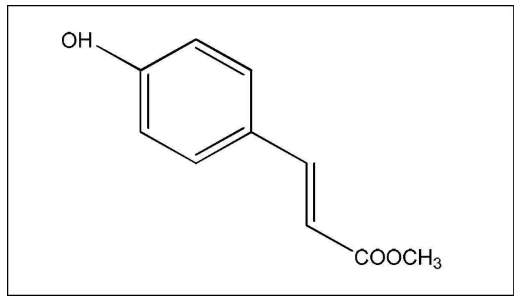

Figure 27: Structure of methyl-3-(4hydroxyphenyl)-2E-propeonate

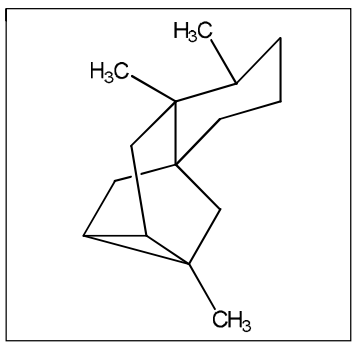

Figure 28: Structure of ishwarane

Discretine (Figure 1a) and nordicentrine (Figure 26), two alkaloids isolated from the stem bark and stem of Xylopia championii Hook., have been subjected to an antifungal 
assay against Clodosporium clodosporioides. It was found that discretine was moderately active (MID $=30$ $\mu \mathrm{g} / \mathrm{spot})$, while nordicentrine was highly active $(6 \mu \mathrm{g} /$ spot) when compared with the standard antifungal agent, benomyl, with an MID value of $1 \mu \mathrm{g} /$ spot (Puvanendran et al., 2008).

The methanol extract from Costus speciosus J. Konig., has led to the isolation of methyl-3-(4hydroxyphenyl)-2E-propeonate (Figure 27) and the compound has inhibited the growth of Aspergillus niger, C. cladosporioides, C. gloeosporioides, Curvularia sp., and Penicillum sp. (Bandara et al., 1988b).

From the hexane extract of the lichen Heterrodermia microphylla, atranorin (Figure 14) has been isolated and the results of quantitative spore germination assay indicated the antifungal activity of atranorin against C. gloeosporioides and C. musae with percentage germination values of 58.2 and 26.2, respectively, while the percentage germination for benlate was 33.3 (Bombuwala et al., 2008).

Ishwarane (Figure 28) has been isolated from the $\mathrm{CH}_{2} \mathrm{Cl}_{2}$ extract of three Hortonia spp. viz., $H$. angustifolia, $H$. floribunda and $H$. ovalifolia. This compound has displayed a moderate antifungal activity against $C$. cladosporioides with a $23 \mathrm{~mm}$ inhibition zone diameter compared with that of the standard antifungal agent benor (37 $\mathrm{mm}$ inhibition zone diameter) in TLC

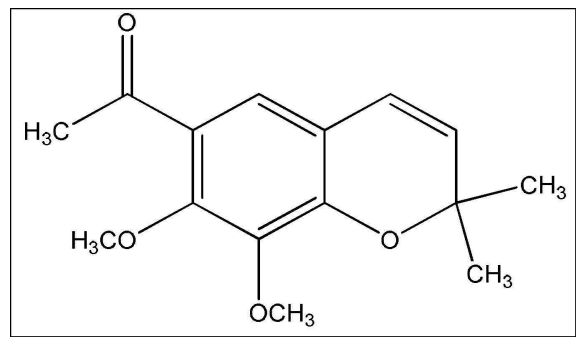

Figure 29: Structure of methylripariochromene A

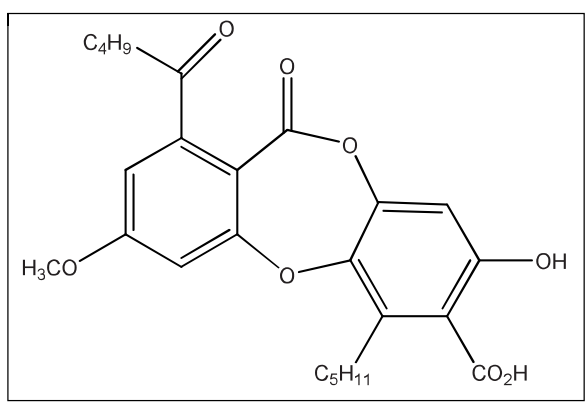

Figure 30: Structure of methyl orsellinate bioassay. This activity has been further corroborated by using germination inhibition assay and found that Ishwarane totally inhibited the germination of C. cladosporioides spores at concentrations higher than 6.25 ppm (Ratnayake et al., 2008).

In the search for active principles from the roots of Eupatorium riparium Regel, methylripariochromene A (Figure 29) has been isolated from $n$-hexane extract and was tested against $C$. gloeosporioides. It has exhibited antifungal activity comparable to that of the commercial fungicide, benlate in TLC bioassay. Results obtained from the germination inhibition bioassay corroborated that methylripariochromene A and benlate had the same degree of antifungal activity against $C$. gloeosporioides (Bandara et al., 1992).

Methyl orsellinate (Figure 30) isolated from Cladonia sp., H. obscurata and $P$. grayana has shown significant antifungal activity against $T$. longifusus, A. flavus, M. canis and $F$. solani. Further, $80 \%$ inhibition was observed for T. longifusus, A. flavus and M. canis while $70 \%$ inhibition was observed for $F$. solani at a concentration of $200 \mu \mathrm{g} / \mathrm{mL}$ (Thadani et al., 2012).

Methyl- $\beta$-orcinolcarboxylate (Figure 31) isolated from Cladonia sp. and $H$. obscurata showed the widest range of antifungal activity, being over $80 \%$ active against T. longifusus, A. flavus, M. canis, F. solani, C. glabrata and C. albicans (Thadani et al., 2012).

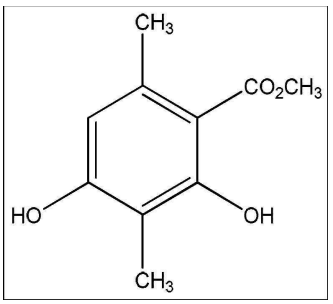

Figure 31: Structure of methyl- $\beta$-orcinolcarboxylate

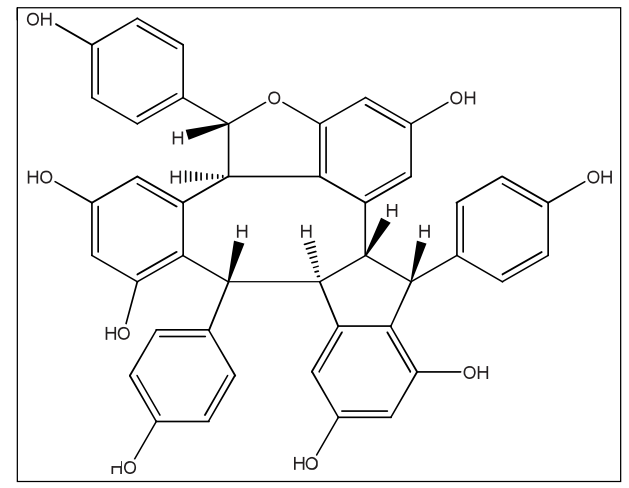

Figure 32: Structure of canaliculatol 


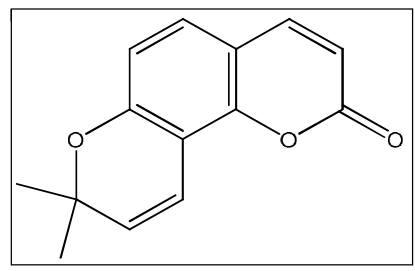

Figure 33: Structure of seselin

The acetone extract of the bark of Stemonoporus canaliculatus Thw. collected from the Kanneliya Forest in the south of Sri Lanka, has shown antifungal activity against the fungus Cladosporium cladosporioides in the TLC spray bioassay. The column chromatographic separation on silica gel has led to the isolation of canaliculatol (Figure 32), which has shown antifungal activity against the fungus Cladosporium cladosporioides (Bokel et al., 1988).

The root bark of Pleiospermium alatum Wight \& Arn., has afforded five alkaloids, five coumarins, lupeol and stigmasterol. One of the acridones, 1,5,6-trihydroxy2,3-dimethoxy-10-methyl-9-acridone is a new record of a compound while another, 1-hydroxy-2,3,5,6tetramethoxy-10-methyl-9-acridone, is a new record of a natural product. However, seselin (Figure 33), a coumarin, has displayed a significant antifungal activity against Cladosporium cladosporioides in TLC bioassay (Bandara et al., 1990a).

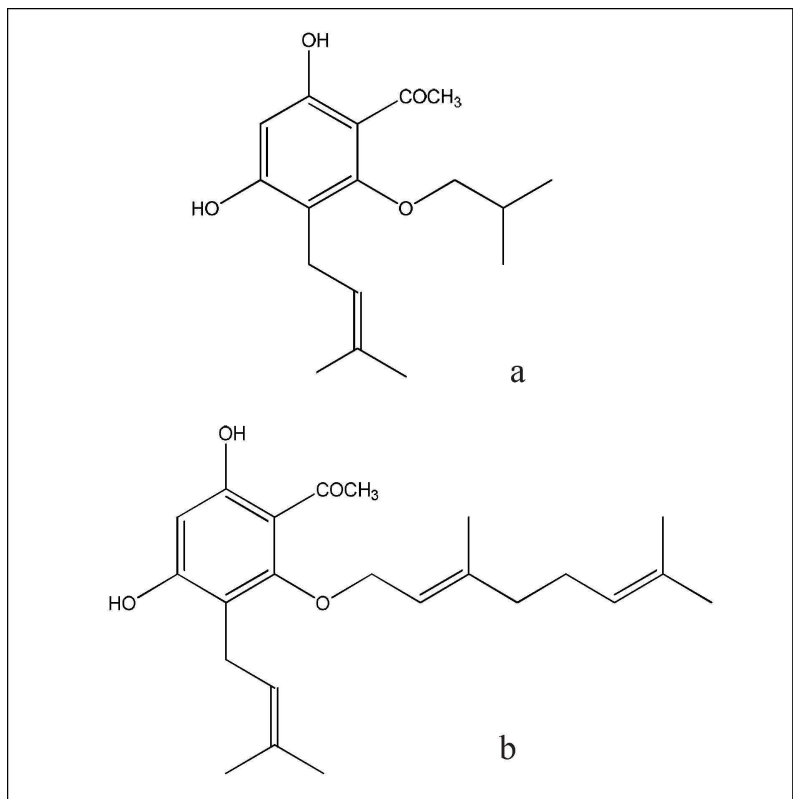

Figure 34: Structure of (a) 1-[2',4'-dihydroxy-6'-(3"-methyl-2"butenyloxy)-5'-(3"-methyl-2"-butenyl)]phenylethanone and (b) 1-[2',4'-dihydroxy-6'-(3",7"-dimethylocta-2", 6"dienyloxy)-5'-(3"-methyl-2"-butenyl)] phenylethanone
Melicope lunu-ankenda (Gaertner) T. Hartley [Euodia lunu-ankenda (Gaertner) Merr.], a species found in Southern Asia, has been used in traditional medicine in Sri Lanka. The neutral fraction of the dichloromethane extract of $M$. lunu-ankenda has shown to be strongly active against the fungus Cladosporium cladosporioides in the TLC bioassay. Chromatography of the fraction has yielded two fungicidal phenylethanones, 1-[2',4'dihydroxy-6'-(3"-methyl-2"-butenyloxy)-5'-(3"-methyl2 "-butenyl)]phenylethanone (Figure 34a) and 1-[2',4'dihydroxy-6'-(3", 7"-dimethylocta-2", 6"-dienyloxy)-5'(3"-methyl-2"-butenyl)] phenylethanone (Figure 34b) (Kumar et al., 1990).

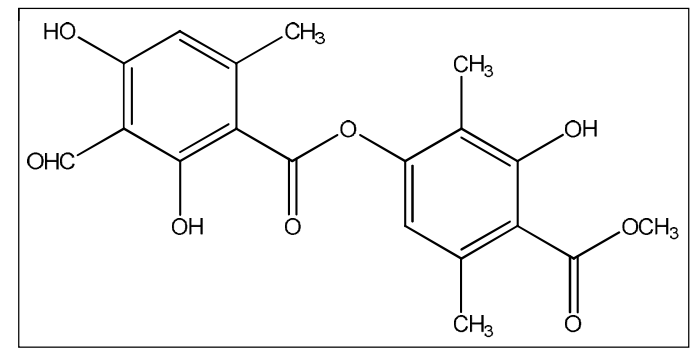

Figure 35: Structure of 3-formyl-2,4-dihydroxy-6-methylbenzoic acid 3-hydroxy-4-Z-methoxycarbonyl-2,5-dimethylphenyl ester

The hexane extract of the stem bark of Gordonia dassanayakei Wadhwa \& Weeras., has shown a high antifungal activity against the plant pathogenic fungi Curvularia sp., Colletotrichum gloeosporioides, Rhizoctonia solani, Corynespora cassiicola, and Fusarium sp.. A compound responsible for the antifungal activity has been isolated and identified as 3-formyl2,4-dihydroxy-6-methylbenzoic acid 3-hydroxy-4-Zmethoxycarbonyl-2,5-dimethylphenyl ester (Figure 35). This active compound inhibited the growth of Curvularia sp., by $17.4 \%$ at a concentration of $0.01 \%$ while the standard compound, benelate inhibited the growth by $42.6 \%$ at the same concentration. The percentage inhibition of growth by the active compound against Rhizoctonia solani, Curvularia sp., Fusarium sp., and Colletotrichum gloeosporioides were 9.3, 32.3, 14.3 and $20.7 \%$, respectively, whilst that by the standard antifungal agent benelate, were 28.4, 63.7, 53.7 and $34.8 \%$, respectively (Athukoralage et al., 2001).

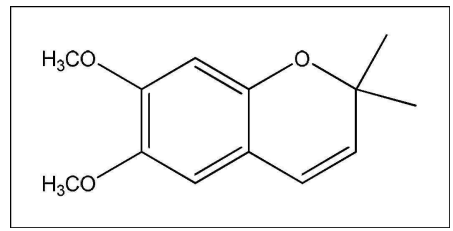

Figure 36: Structure of precocene II 
Ageratum conyzoides L., is an annual herb that grows in the tropics and subtropics of which, the extracts are known to possess pharmacological and biocidal activity. The organic solvent extracts from the shoots have been tested for antifungal activity against the plant pathogenic fungi Rhizoctonia solani, Sclerotium rolfsii, Botryodiplodia theobromae, Phomopsis theae and Fusarium species growing in vitro on potato dextrose agar medium. The crude $n$-hexane extract completely inhibited the growth of $R$. solani and $S$. rolfsii. Activity guided fractionation of the $n$-hexane extract has yielded an antifungal compound precocene II (Figure 36), which exhibited $100 \%$ inhibition of $R$. solani and S. rolfsii at a concentration of $80-100 \mathrm{ppm}$. The sclerotia of $R$. solani and $S$. rolfsii were also completely suppressed by precocene II at $150 \mathrm{ppm}$ (Iqbal et al., 2004).
The antifungal activity guided fractionation of the $n$-butanol extract of the methanol extract of the stem bark of Artocarpus nobilis Thwaites has furnished two stilbene derivatives (E)-4-isopentenyl-3,5,20,40tetrahydroxystilbene (Figure 3a) and (E)-4-(3-methyl-Ebut-1-enyl)-3,5,20,40-tetrahydroxystilbene (Figure 3b). Both compounds have shown strong antifungal activity at $10 \mu \mathrm{g} / \mathrm{spot}$ against Cladosporium cladosporioides on TLC bio-autography method.

Antifungal activity guided fractionation of solvent extracts of the stem bark of Bridelia retusa Spreng., belonging to the family Euphorbiaceae against Cladosporium cladosporioides furnished new bisabolane sesquiterpenes (E)-4-(1,5-dimethyl-3-oxo-1hexenyl)benzoic acid (Figure 37a), (E)-4-(1,5-dimethyl-

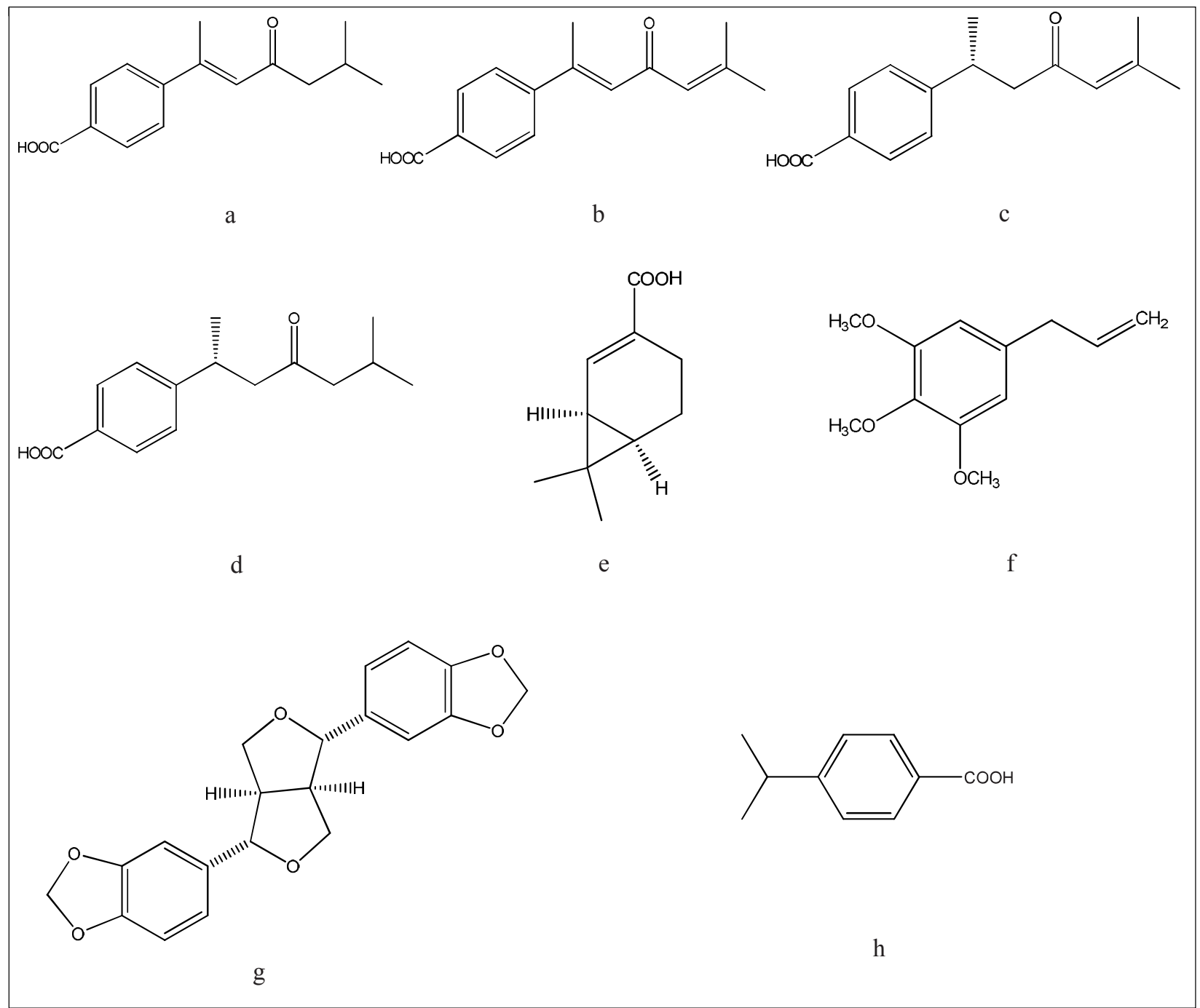

Figure 37: Structure of (a) (E)-4-(1,5-dimethyl-3-oxo-1-hexenyl)benzoic acid; (b) (E)-4-(1,5-dimethyl-3-oxo-1,4-hexadienyl) benzoic acid; (c) (R)-4-(1,5-dimethyl-3-oxo-4-hexenyl)benzoic acid; (d) (-)-isochaminic acid; (e) (R)-4-(1,5-dimethyl-3-oxohexyl)benzoic acid (ar-todomatuic acid);, (f) 5-allyl-1,2,3-trimethoxybenzene (elemicin); (g) (+)-sesamin and (h) 4-isopropylbenzoic acid 
3-oxo-1,4-hexadienyl) benzoic acid (Figure 37b), (R)-4(1,5-dimethyl-3-oxo-4-hexenyl)benzoic acid (Figure 37c) and (-)-isochaminic acid (Figure 37d), together with the known (R)-4-(1,5-dimethyl-3-oxohexyl)benzoic acid (ar-todomatuic acid) (Figure 37e), 5-allyl-1,2,3trimethoxybenzene (elemicin) (Figure 37f), (+)-sesamin (Figure 37g) and 4-isopropylbenzoic acid (cumic acid) (Figure 37h). All these compounds have shown fungicidal activity on TLC bioautography method at very low concentrations except elemicin (Jayasinghe et al., 2003).

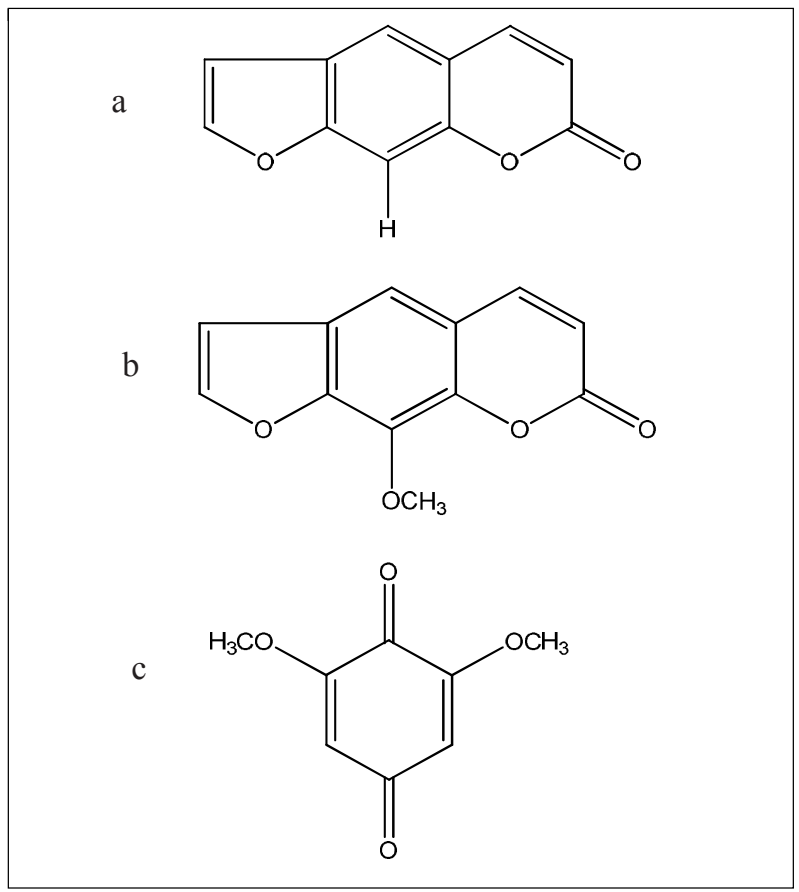

Figure 38: Structure of (a) psoralene; (b) xanthotoxin and (c) 2,6dimethoxybenzoquinone

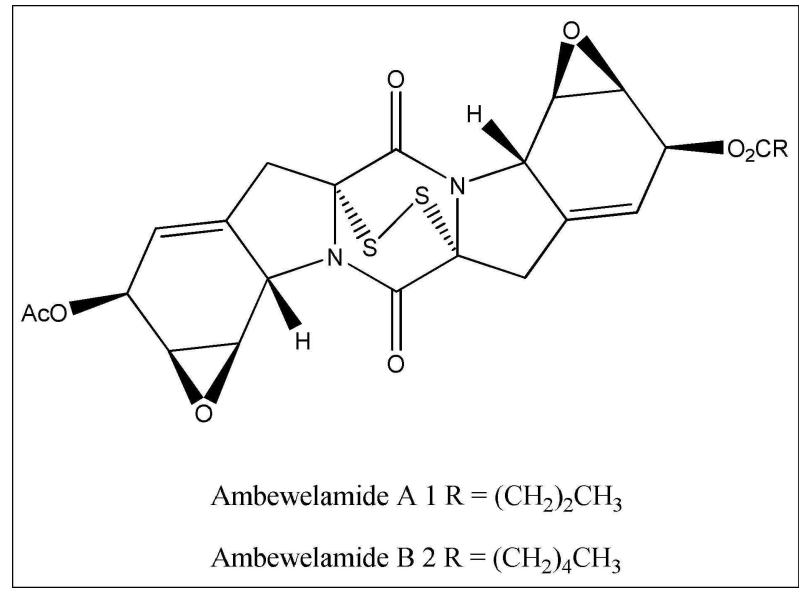

Figure 39: Structure of ambewelamide A and $B$
The unripened fruit of Limonia acidissima L., was extracted into chloroform and the TLC Cladosporium bioassay showed three compounds, psoralene (Figure 38a), xanthotoxin (Figure 38b) and 2,6dimethoxybenzoquinone (Figure 38c), which were able to inhibit the growth of Cladosporium (Adikaram et al., 1989).

\section{Anticancer activity}

Cancer has no geographic, national, religious or other boundaries. Each year over 6.5 million people are diagnosed with cancer worldwide (Culotta \& Koshland, 1993). Natural products and their semisynthetic analogues have provided some of the most effective and widely used chemotherapeutic agents for cancer (Cordel, 1978). This is exemplified by such compounds as Taxol ${ }^{\circledR}$, the Vinca alkaloids, vinblastine, vincristine, the podophyllotoxin analogues etoposide and teniposide, the camptothecin analogues topotecan, and CPT-11, the microbial products bleomycin, mitomycin $\mathrm{C}$, the anthracyclines adrimycin and daunorubicin. Importantly, these anticancer compounds are highly complex that they would not have emerged from a synthetic programme alone or from the combinatorial approach to drug discovery. Thus, natural products approach continues to be important for the development of new anticancer drugs as it is complementary to synthetic and biosynthetic approaches.

Two new members of a family of highly modified phenylalanine diketopiperazine, ambewelamide A and $\mathrm{B}$ (Figure 39) have been isolated from the $\mathrm{CH}_{2} \mathrm{Cl}_{2}$ extract of Usnea sp., found in Ambewela, Sri Lanka. Of the two compounds, ambewelamide A exhibited potent in vitro cytotoxicity against murine leukemia P388 cells with an $\mathrm{IC}_{50}$ value of $8.6 \mathrm{ng} / \mathrm{mL}$ and showed significant in vitro antineoplastic activity against P388 cells (percentage $\mathrm{T} / \mathrm{C} 140$ at $160 \mu \mathrm{g} / \mathrm{kg}$ ) (Williams et al., 1998).

A flabelliferin (Figure 40) isolated from the methanol: water (1:1) extract of Borassus flabellifera L., flour was introduced into micro wells containing melanoma cells. A $13 \%$ inhibition of the cell growth has been observed for the isolated compound at the concentration of $100 \mu \mathrm{g} / \mathrm{mL}$ on the melanoma cell line, while the reference compound, doxorubicin resulted in a $63 \%$ inhibition of cell growth at the concentration of $20 \mu \mathrm{g} / \mathrm{mL}$ (Keerthi et al., 2009).

Seselin (Figure 33) isolated from Pleiospermium alatum Radlk., has shown detectable activity against a yeast strain rad 52, at a dose of $500 \mu \mathrm{g} / \mathrm{mL}$. Further, seselin has shown selective activity against the rad 52 yeast strain as compared with the wild-type $\mathrm{RAD}^{+}$ 


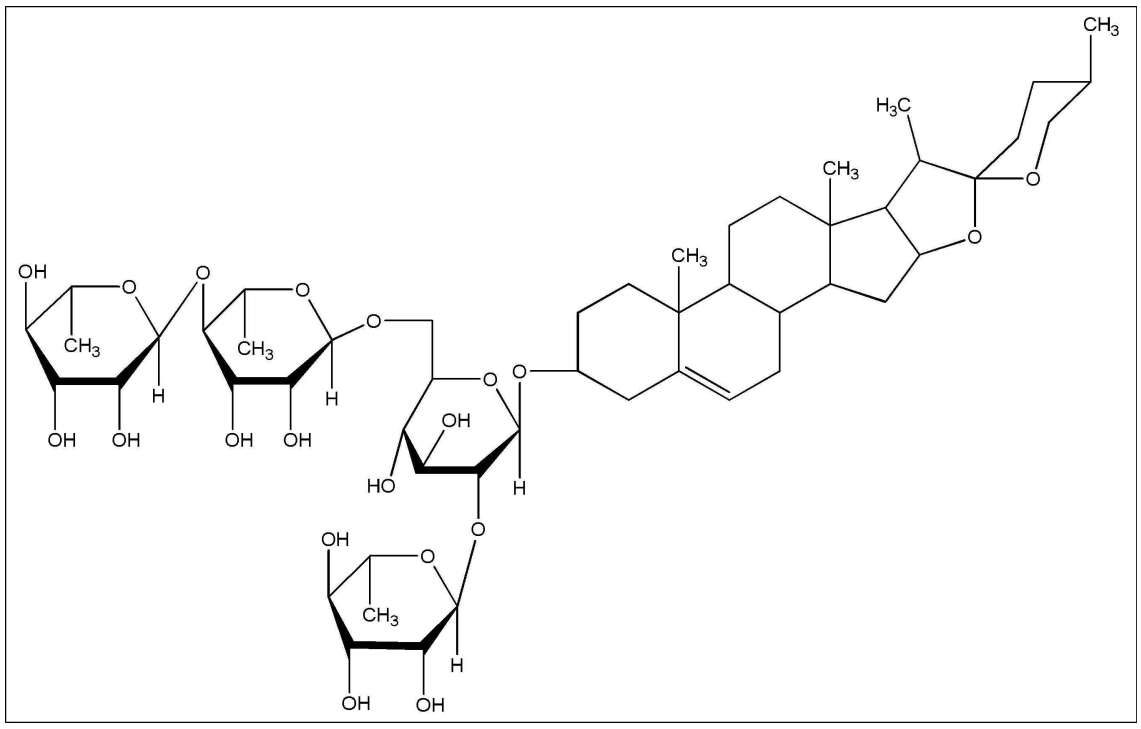

Figure 40: Structure of flabelliferin

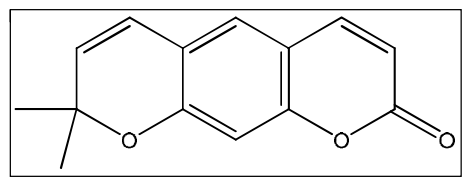

Figure 41: Structure of xanthyletin

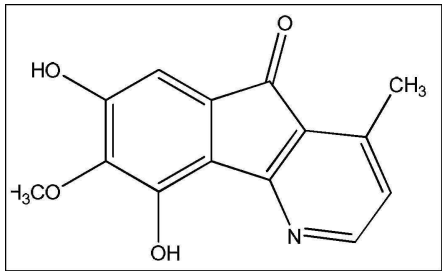

Figure 42: Structure of cyathocaline

strain, indicating that it functions as a DNA-damaging agent. Seselin was also weakly active in a mammalian cytotoxicity assay against Vero monkey cells, with an $\mathrm{IC}_{50}$ value of $12 \mu \mathrm{g} / \mathrm{mL}$ (Gunatilaka et al., 1994).

The other compound isolated from Pleiospermium alatum was xanthyletin (Figure 41), which has shown somewhat higher activity in the wild-type $\mathrm{RAD}^{+}$cell line $\left(\mathrm{IC}_{50}\right.$ value $\left.=21 \mu \mathrm{g} / \mathrm{mL}\right)$ suggesting that its cytotoxicity is due to some other mechanism than the DNA damage (Gunatilaka et al., 1994).

Cyathocalyx zeylanica Champ. ex Hook., is a plant belonging to the family Annonaceae. Bioactivityguided fractionation of the methanol extract of the stem bark of $C$. zeylanica has afforded a moderately bioactive new azafluorenone alkaloid, cyathocaline (Figure 42), the structure of which was established as 5,7-dihydroxy-6-rnethoxy-1-methyl-4-azatluoren-9-one. Cyathocaline exhibited moderate but selective activity in the mechanism-based yeast bioassay for DNAmodifying agents with the following $\mathrm{IC}_{50}$ values: $\mathrm{RS}$ 322 YK (rad52Y), $90 \mu \mathrm{g} / \mathrm{mL}$; RS $321 \mathrm{~N}, 87 \mu \mathrm{g} / \mathrm{mL}$; RS $188 \mathrm{~N}\left(\mathrm{RAD}^{+}\right)>400 \mu \mathrm{g} / \mathrm{mL}$; inactive in the RS 167 $\mathrm{N}($ rad6) strain. In a cytotoxicity test against the A-549 human lung carcinoma cell line, it had an $\mathrm{IC}_{50}$ value of $8.5 \pm 0.07 \mu \mathrm{M}$ (Wijeratne et al., 1995).

The stem bark of Pleurostylia opposita Wall., has been extracted with $\mathrm{MeOH} / \mathrm{CH}_{2} \mathrm{Cl}_{2}(1: 1 \mathrm{v} / \mathrm{v})$. Size extrusion of the purified extract yielded two sesquiterpene pyridine alkaloids, oppositines A (Figure 43a) and B (Figure 43b). Oppositines A and B when exposed to the cancer cell line HCT-116 (human colon tumor) have shown moderate cytotoxicity against HCT116 cell lines with $\mathrm{EC}_{50}$ values of $27 \pm 2$ and $26 \pm 3 \mu \mathrm{M}$, respectively (Whitson et al., 2006).

The lichen Parmotrema sp. (Parmeliaceae), collected from Labukelle, Central Province, Sri Lanka, has been sequentially extracted into methanol and the extract has shown significant in vitro kinase inhibitory activity. Bioassay-guided fractionation of the Parmotrema sp., extract has led to the isolation of depside inhibitors. A new depside (Figure 44a) has been isolated along with two known metabolites, $\beta$-collatolic acid (Figure 44b) and $\beta$-alectoronic acid (Figure $44 \mathrm{c}$ ). These three depsides, depside $\beta$-collatolic acid and $\beta$-alectoronic acid have 


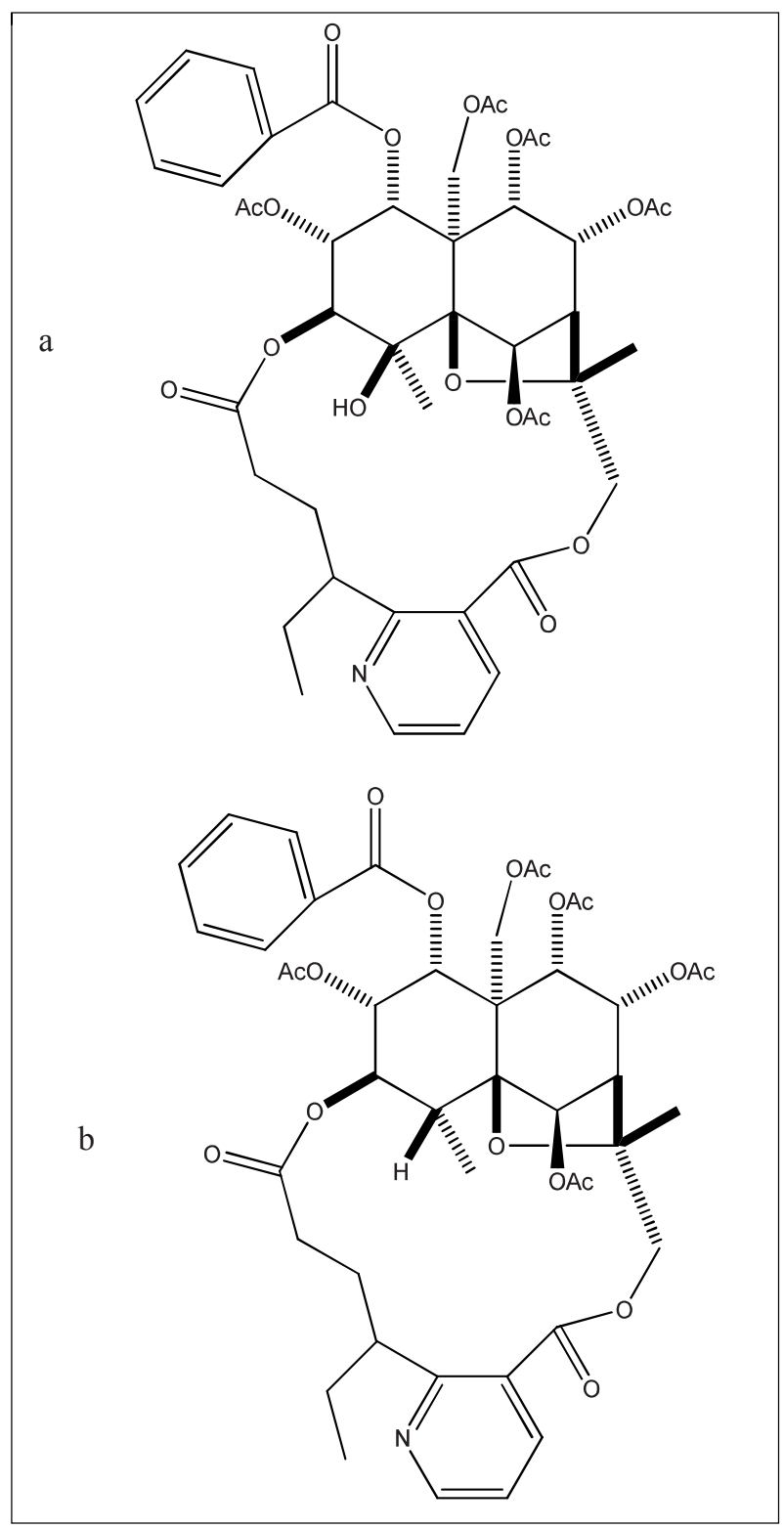

Figure 43: Structure of (a) oppositines A and (b) oppositines B

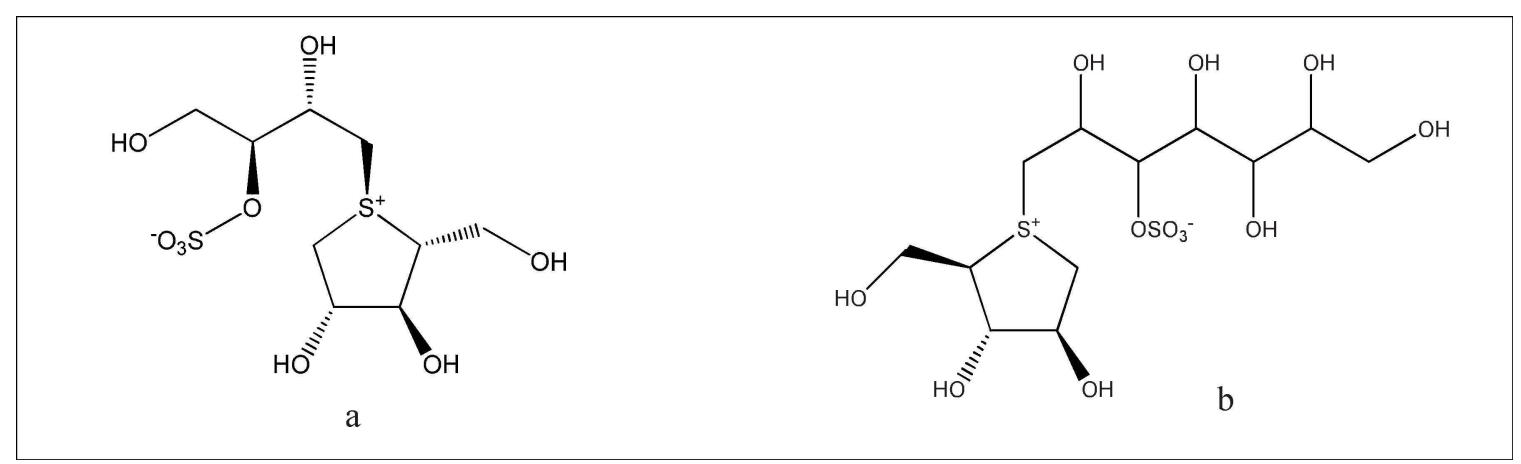

Figure 45: Structure of (a) salacinol and (b) kotalanol 
exhibited moderate inhibition of purified recombinant Plk1 kinase with $\mathrm{IC}_{50}$ values of $2.8,0.7$, and $1.7 \mu \mathrm{M}$, respectively at $1 \mu \mathrm{MATP}$. The inhibitory activity has been also observed at high ATP concentrations, suggesting the potential for activity in a cellular environment. The depsides when tested against a panel of 23 other recombinant inases were found to possess up to 30-fold selectivity toward Polo-like kinase-1 (Williams et al., 2011).

\section{Oral hypoglycaemic activity}

Diabetes mellitus is a chronic disorder of carbohydrate, fat, and protein metabolism (Anirban \& Abdul, 2005). A defective or deficient insulin secretory response causes impaired carbohydrate (glucose) use and the resultant hyperglycaemia is a typical feature of diabetes mellitus. It is the fourth leading cause of death in developed countries and diabetes mellitus affects more than $5 \%$ of the world's population, making it one of the most common non communicable diseases (2001). There are more than 220 million persons affected with diabetes in the world today, and by 2025 , the number is expected to approach 300 million (Simon, 2010). A standard treatment uses drugs such as sulphonyl ureas, biguanides and thiazolidinediones, which reduce hyperglycaemia by inducing $\beta$-cells to produce more insulin. However, undesired consequences of prolonged use of sulphonylureas and other drugs include hypoglycaemic episodes, ultimate exertion of $\beta$-cell and long term angiogenic side effects, which result due to chronic exposure to increased insulin levels (Bebernitz et al., 2001).

A large number of medicinal plants used in the control of diabetes mellitus have been reported (Bailey \& Day, 1989; Marles \& Farnsworth, 1994). Although these plants may represent alternatives to developing new oral hypoglycaemic agents, appropriate and unambiguous ethnobotanical information is needed to exploit them.

Salacia reticulata Wight., is an indigenous plant, which grows in the Dry Zone forests of Sri Lanka. Known as kothala himbutu, this herb is used for the treatment of diabetes in ayurvedic medicine. A polyhydroxylated cyclic 13-membered sulfoxide, salacinol (Figure 45a) has been isolated from an aqueous extract of $S$. reticulata through bioassay guided separation. Salacinol has shown potent inhibitory activities on several $\alpha$-glucosidases such as maltase, sucrase and isomaltase, and the inhibitory effects on serum glucose levels in maltose and sucrose-loaded rats (in vivo) have been found to be more potent than that of acarbose, a commercial a-glucosidase inhibitor. The $\alpha$-glucosidase inhibitory activity of salacinol is also reported $\left(\mathrm{IC}_{50}\right.$ : maltase, $3.2 \mathrm{mg} / \mathrm{mL}$; sucrase, $0.84 \mathrm{mg} / \mathrm{mL}$; isomaltase, $0.59 \mathrm{mg} / \mathrm{mL}$ ). Interestingly, the organic extracts of the plant contained triterpenoids (Gunatilaka et al., 1993; Tezuka et al., 1993; 1994; Dhanabalasingham et al., 1996).

A potent natural $\alpha$-glucosidase inhibitor, kotalanol (Figure 45b) ( $\mathrm{IC}_{50}:$ maltase, $2.8 \mathrm{mg} / \mathrm{mL}$; sucrase, 0.58 $\mathrm{mg} / \mathrm{mL}$; isomaltase, $1.9 \mathrm{mg} / \mathrm{mL}$ ) has been isolated from the roots and stems of $S$. reticulata.

Several studies on the chemistry of $S$. reticulata have been conducted using $S$. reticulata var. diandra, a variety endemic to Sri Lanka (Karunaratne, 2013). According to the current literature (Dassanayake, 1996), this variety is now elevated to the species level (S. diandra).

\section{$\alpha-$ Glucosidase inhibitory activity}

$\alpha$-Glucosidase inhibitors have proved useful in the reduction of postprandial hyperglycaemia by suppressing the absorption of glucose, being effective in the treatment of type II diabetes and obesity (Raskin et al., 2007). The current interest in these compounds has been extended to a diverse range of diseases, including lysosomal storage disorders, cancer and special attention has been given to those compounds with anti-HIV activity (Kouam et al., 2006). Because of their promising therapeutic potential, $\alpha$-glycosidase inhibitors are being searched from natural

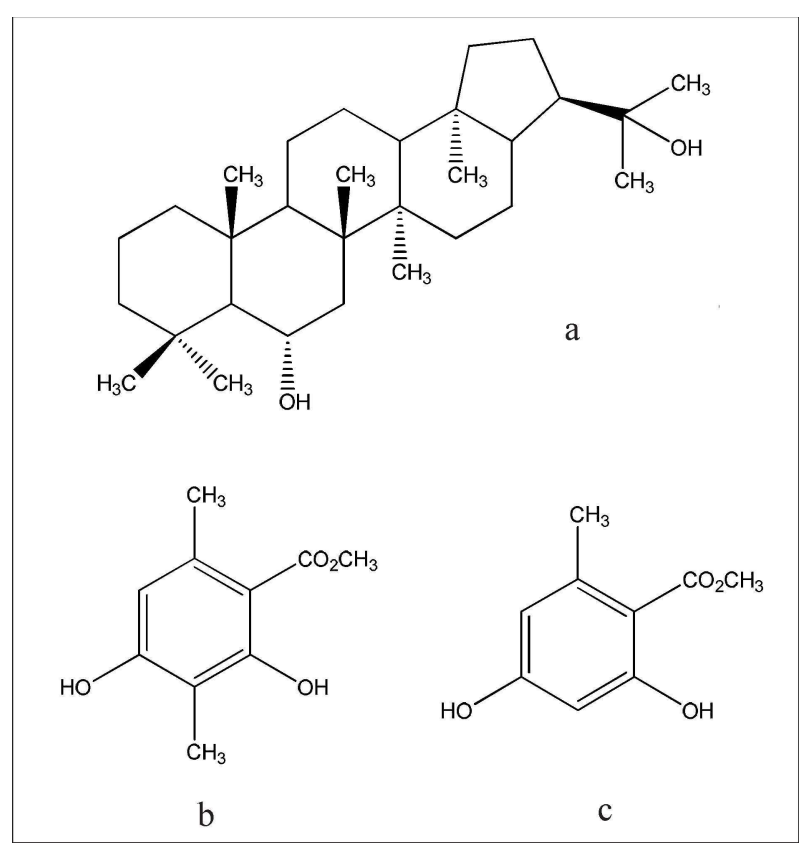

Figure 46: (a) zeorin; (b) methyl- $\beta$-orcinol carboxylate and (c) methyl orsellinate 
sources. Polyhydroxy glycosidase inhibitors are a widely diverse class of compounds often isolated from plants and microorganisms, which have significant therapeutic potential (Melo et al., 2006). Carbocyclic compounds include potent HIV inhibitors such as conduritol epoxides and aminoconduritols, while conduritol A analogues modulate the release of insulin (Abbasi et al., 2005). Thiosugars, either synthesized or isolated from natural sources, have also been investigated as inhibitors and have widened the structural diversity of such compounds available from natural sources. Compounds with no obvious structural similarity to a carbohydrate skeleton are a new class of inhibitors and the elucidation of their mechanism of action may add new insights in the search for new therapeutic agents (Melo et al., 2006).

Three compounds, zeorin (Figure 46a), methyl- $\beta$ orcinol carboxylate (Figure 46b), and methyl orsellinate (Figure 46c), have been isolated from dichloroform and methanol fractions of dried lichens Parmolrema grayana and Cladonia sp.. These three compounds, zeorin ( $\mathrm{IC}_{50}$ $=100.0 \pm 0.3 \mu \mathrm{M})$, methyl- $\beta$-orcinol carboxylate $\left(\mathrm{IC}_{50}=\right.$ $140.0 \pm 0.6 \mu \mathrm{M})$, and methyl orsellinate $\left(\mathrm{IC}_{50}=165.0 \pm\right.$ $1.2 \mu \mathrm{M})$, has shown tremendous $\alpha$-glucosidase inhibitory activity showing lower $\mathrm{IC}_{50}$ values compared to the standard compounds 1-deoxynojirimycin $\left(\mathrm{IC}_{50}=425.0 \pm\right.$ $8.9 \mu \mathrm{M})$ and acarbose $\left(\mathrm{IC}_{50}=700.0 \pm 10.4 \mu \mathrm{M}\right)($ Thadani et al., 2011).

\section{Sperm motility enhancing activity}

Globally, infertility affects about 50 to 80 million couples at some point of their reproductive lives with a variety of biological and behavioural determinants (World Health Organisation, 2003). There is a need and a demand for new sperm stimulants to be used in asthenozoospermia and in some assisted reproductive programmes. In many parts of the world, efforts are now being aimed at investigating the therapeutic efficacy of locally available medicinal herbal plants. The beneficial role of medicinal plants in the treatment of male infertility has been numerously indicated (Saalu et al., 2006; 2009a; 2009b; 2010).

The development of new fertility regulating drugs from medicinal plants is an attractive proposition. Natural plant substances possessing mild inherent estrogenic or anti-estrogenic properties offer themselves as effective non-conventional sources of contraception with less deleterious side effects. Many plants and herbs have also been reported to have potential antifertility properties (Casey, 1960). Many of these plant products having inherent estrogenic or anti-estrogenic effects possibly bring about alterations in tubal transport of blastocyst or hormonal milieu of the uterus making the uterine environment hostile for implantation or fetal development.

A steroid glycoside 1 (Figure 47) isolated from Sri Lankan soft coral Sinularia crispa showed a spermatostatic activity on rat cauda epididymal spermatozoa (Tillekeratne et al., 1989).

A non-steroidal contragestative agent (Figure 48) has been isolated from the $\mathrm{MeOH}-\mathrm{CH}_{2} \mathrm{Cl}_{2}(1: 1)$ crude extract of the Sri Lankan marine red algae, Gelidiella acerosa. Contragestative effects of this compound assessed in pregnant rats has shown $80 \%$ contragestative activity without any overt clinical signs of toxicity (Premakumara et al., 1996).

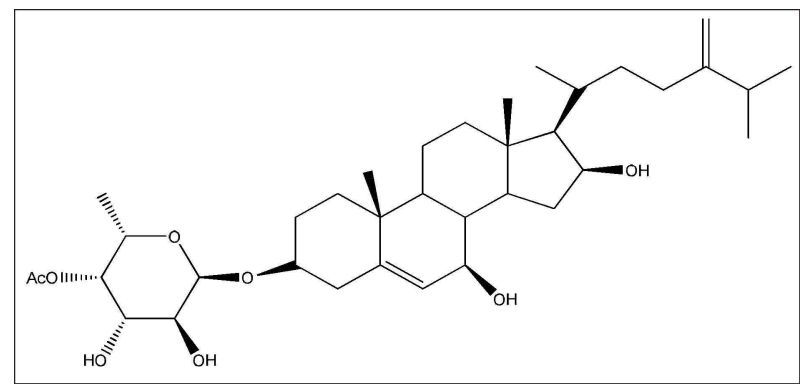

Figure 47: Structure of steroid glycoside 1 from Sri Lankan soft coral Sinulariacrispa

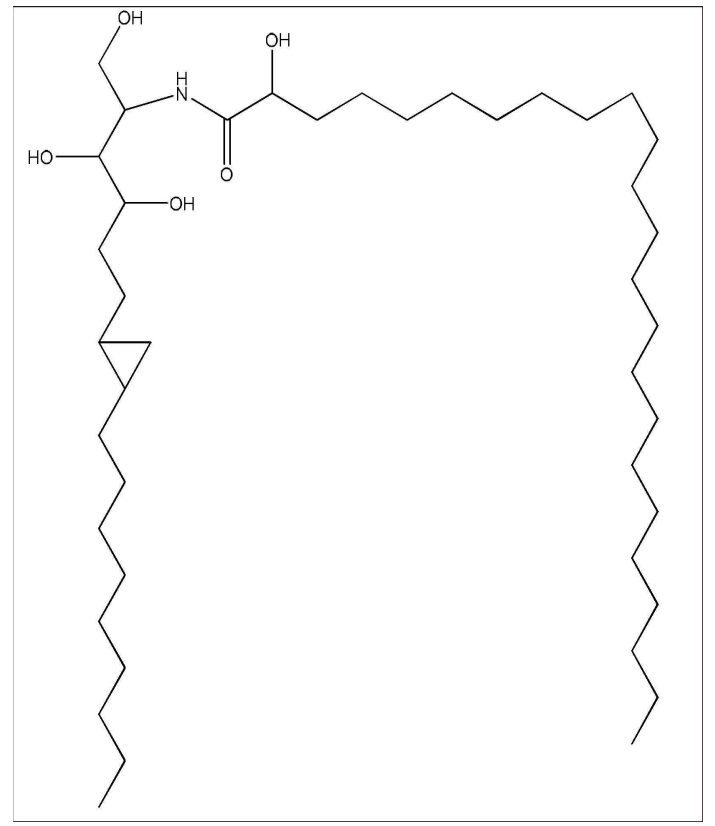

Figure 48: Structure of non-steroidal contragestative agent isolated from Sri Lankan soft coral Sinulariacrispa 


\section{Anti-inflammatory activity}

Although, no bioactive compounds in this category have been isolated so far, Sri Lankan studies on the antiinflammatory activity is significant because bioassays carried out on crude extracts have shown the potential of Sri Lankan plants having anti-inflammatory activity.

Leaves of Argyreia populifolia Choisy (Convolvulaceae) is used in the traditional medicine for inflammation in joints and arthropod bites. The anti-inflammatory activity of the leaves have been evaluated using carrageenan-induced paw oedema test in rats. A $10 \mathrm{~mL} / \mathrm{kg}$ oral dose of fresh juice of the leaves significantly impaired the initial phase of the acute inflammatory response (by 33\%) in this model. The juice has shown a marked anti-histamine activity when assessed using histamine-induced vascular permeability test. It has been concluded that the leaf juice has an antiinflammatory activity mediated via antihistamine action, justifying its use in traditional medicine (Ratnasooriya \& Dharmasiri, 2001).

The anti-inflammatory potential of an aqueous leaf extract (ALE) of Ixora coccinea (Rubiaceae) in rats after oral administration (500, 1000 and $1500 \mathrm{mg} / \mathrm{kg}$ ) has also been investigated. This has been done using the carrageenan-induced paw oedema (acute inflammatory model) and cotton pellet granuloma tests (chronic inflammatory model). In the former test, ALE significantly reduced both early and late phases of the inflammatory response and also the oedema maintained between the two phases. In the latter test, it has significantly suppressed granuloma formation (only highest dose tested). Collectively, the results has shown a promising anti-inflammatory activity against both acute and chronic inflammation (Ratnasooriya et al., 2005). The anti-inflammatory activity of methanolic leaf extract (MLE) of I. coccinea Linn. (Rubiaceae), has also been investigated. It has been found that the methanolic leaf extract has a dose-dependent anti-inflammatory activity in carrageenan-induced rat paw oedema model $\left(\mathrm{r}^{2}=0.7\right.$; $\mathrm{p}<0.01$ ) (Handunnetti et al., 2009).

Trichosanthes cucumerina Linn. (Cucurbitaceae), is one of the medicinal plants often used in Sri Lankan traditional medicine. The anti-inflammatory activity of the hot water extract and its fractions of T. cucumerina have been evaluated by the use of carrageenan-induced paw oedema model in Wistar rats. Apart from the lowest dose of the HWE, other tested doses (500, 750, $1000 \mathrm{mg} / \mathrm{kg})$ produced a significant $(\mathrm{p} \leq 0.05)$ inhibition of the inflammation, most pronounced at 5 hours after the injection of carrageenan. The anti-inflammatory effect induced by $750 \mathrm{mg} / \mathrm{kg}$ was comparable to that of the reference drug, indomethacin at 4 and 5 hours (Arawwawala et al., 2010).

Vitex negundo L. (Verbenaceae) is a small tree, of which the water extract of fresh mature leaves is used internally and externally in ayurveda medicine as antiinflammatory, analgesic and anti-itching agents. The early phase ( 2 hours) of carrageenan-induced rat paw oedema was significantly $(\mathrm{p}<0.01)$ suppressed in an inversely does-dependent $\left(r^{2}=1, p<0.01\right)$ manner by fresh mature leaf extract $\left(\mathrm{EC}_{50}=2 \mathrm{~g} / \mathrm{kg}\right)$. In the formaldehyde-induced rat paw oedema test, the 2.5 and $5 \mathrm{~g} / \mathrm{kg}$ leaves have significantly $(\mathrm{p}<0.05)$ suppressed the inflammation on days $4-6$ of the test (Dharmasiri et al., 2003).

The anti-inflammatory potential of Sri Lankan black tea (Camellia sinensis L.) (Theaceae) has been determined using both acute (carrageenan-induced paw oedema) and chronic (formaldehyde-induced paw oedema and cotton pellet granuloma test) rat inflammatory models. Three doses of black tea brew (BTB) $[84 \mathrm{mg} / \mathrm{mL}$, equivalent to 1.5 cups; $168 \mathrm{mg} / \mathrm{mL}$, equivalent to 3 cups; and 501 $\mathrm{mg} / \mathrm{mL}$, equivalent to 9 cups] made using high grown unblended dust grade No: 1 black tea samples were orally administered to rats $(n=6-9 /$ dose/test). The results have shown that Sri Lankan BTB possesses marked and significant $(\mathrm{p}<0.05)$ oral anti-inflammatory activity against both acute and chronic inflammation. This anti-inflammatory activity was dose-dependent in the carrageenan-induced paw oedema test and cotton pellet granuloma test. Further, in the carrageenan paw oedema model, the anti-inflammatory activity of BTB was almost identical to the green tea brew of both Chinese and Japanese types (Ratnasooriya \& Fernando, 2009).

In Sri Lankan traditional medicine a decoction of leaves and stems of Anisomeles indica (Lamiaceae) is claimed to possess anti-inflammatory activity. Three doses of the freeze-dried decoction of a pre-flowering plant (E1) $(125,250$ and $500 \mathrm{mg} / \mathrm{kg})$ and one dose of the decoction of a plant at flowering stage (E2) (500 mg/ $\mathrm{kg})$ were orally administered to rats. The anti-inflammatory activity has been evaluated using the carrageenaninduced paw edema, formaldehyde-induced paw oedema and adjuvant-induced paw oedema models in rats. E1 demonstrated a significant $(\mathrm{p}<0.01)$ and dose-dependent anti-inflammatory effect in all three models, while E2 did not demonstrate significant anti-inflammatory activity (Dharmasiri et al., 2002). 


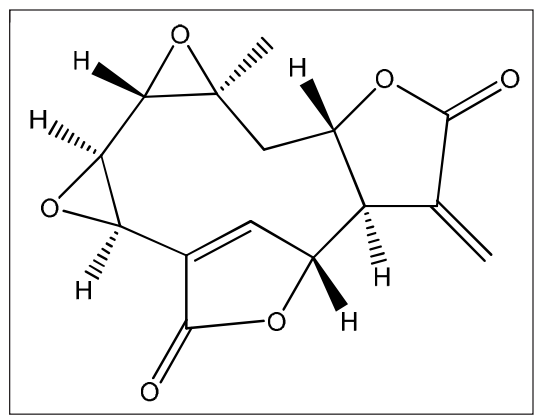

Figure 49: Structure of mikanolide

\section{Miscellaneous activity}

Mikania scandens B. L. Rob., is a common invasive plant in Sri Lanka and other South Asian countries. Preliminary investigation of a number of plant extracts for allelopathic activity using seed germination inhibition bioassay has shown promising bioactivity of the water extract of the aerial parts of $M$. scandens. Activity-guided fractionation of the $M$. scandens extract led to the isolation of the highly allelopathic active compound mikanolide (Figure 49), with an MIC of $0.083 \mu \mathrm{M} / \mathrm{mL}$. This plant could be used to develop as an environment friendly natural herbicide, either in crude form as shredded plant material or as pure mikanolide, which is the major constituent $(\sim 0.02 \%)$ in the plant (Piyasena \& Dharmaratne, 2013).

\section{CONCLUSION}

Bioactive compounds ranging from alkaloids, terpenoids, aromatic compounds and lichen specific metabolites isolated from Sri Lankan flora exhibits the potential of the Sri Lankan flora as an economic resource. In light of these findings, a comprehensive investigation of bioactive compounds of Sri Lankan endemic plants has now become of prime importance.

\section{REFERENCES}

1. Abbasi A.A., Ahmad V.U., Zubair M., Rashid M.A., Khan S.N., Faroog U., Choudhary M.I. \& Zeller K.P. (2005). A new $\alpha$-glucosidase inhibiting dithiadiazetidin derivative from Symplocos racemosa. Heterocycles 65(8): 1837 -1842 .

DOI: http://dx.doi.org/10.3987/COM-05-10417

2. Adikaram N.K.B., Abhayawardhane Y., Gunatilaka A.A.L., Bandara B.M.R. \& Wijeratne E.M.K. (1989). Antifungal activity, acid and sugar content in the wood apple (Limonia acidissima) and their relation to fungal development. Plant Pathology 38(2): 258 - 265.

DOI: http://dx.doi.org/10.1111/j.1365-3059.1989.tb02141.x
3. Adikaram N.K.B., Karunaratne V., Bandara B.M.R., Hewage C.M., Abayasekara C. \& Mendis B.S.S. (2002). Antifungal properties of plumbagin. Journal of the National ScienceFoundation of Sri Lanka 30(3\&4): 89 - 95. DOI: http://dx.doi.org/10.4038/jnsfsr.v30i3-4.2498

4. Anirban M. \& Abdul K.A. (2005). The Endocrine System. Elsevier Publishing, New Delhi, India.

5. Arawwawala M., Thabrew I.,Arambewela L. \& Handunnetti S. (2010). Anti-inflammatory activity of Trichosanthes cucumerina Linn. in rats. Journal of Ethnopharmacology 131(3): $538-543$.

DOI: http://dx.doi.org/10.1016/j.jep.2010.07.028

6. Arseculeratne S.N., Gunatilaka A.A.L. \& Panabokke R.G. (1985). Studies of medicinal plants of Sri Lanka - part 14: toxicity of some traditional medicinal herbs. Journal of Ethnopharmacology 13(3): 323 - 335.

7. Athukoralage P.S., Herath H.M.T.B., Deraniyagala S.A., Wijesundera R.L.C. \& Weerasinghe P.A. (2001). Antifungal constituent from Gordonia dassanayakei. Fitoterapia 72(5): $565-567$.

8. Atta-ur-Rahman \& Choudhary M.I. (2001). Bioactive natural products as a potential source of new pharmacophores: a theory of memory. Pure and Applied Chemistry 73(3): $555-560$.

9. Attygalle J. (1917). Sinhalese Materia Medica. M.D. Gunasena \& Co. Ltd., Colombo.

10. Bailey J. \& Day C. (1989). Traditional plant medicines as treatments for diabetes. Diabetes Care 12: 553 - 564. DOI: http://dx.doi.org/10.2337/diacare.12.8.553

11. Bandara B.M.R., Wimalasiri W.R. \& Bandara K.A.N.P. (1987). Isolation and insecticidal activity of (-)-hardwickiic acid from Crotn aromaticus. Planta Medica 53(6): 575.

12. Bandara B.M., Hewage C.M., Karunaratne V. \& Adikaram N.K. (1988a). Methyl ester of para-coumaric acid: antifungal principle of the rhizome of Costus speciosus. Planta Medica 54(5): 477 - 478.

DOI: http://dx.doi.org/10.1055/s-2006-962518

13. Bandara B.M.R., Wimalasiri W.R. \& Macleod J.K. (1988b). Ent-kauranes and oleananes from Croton lacciferus. Phytochemistry 27(3): $869-871$.

14. Bandara B.M., Cortes D., Jayasinghe U.L., Karunaratne V., Sotheeswaran S. \& Wannigama G.P. (1989a). Aporphine alkaloids from Litsea gardneri and Actinodaphne speciosa. Planta Medica 55(4): 393.

DOI: http://dx.doi.org/10.1055/s-2006-962039

15. Bandara B.M.R., Fernando I.S.H., Hewage C.M., Karunaratne V., Adikaram N.K.B. \& Wijesundara D.S.A. (1989b). Antifungal activity of some medicinal plants of Sri Lanka. Journal of the National Science Council of Sri Lanka 17(7): 1 - 13.

16. Bandara B.M.R., Gunatilaka A.A.L., Sotheswaran S. \& Wijeratne E.M.K. (1989c). Insecticidal properties and an active constituent of Limonia acidissimia. Journal of the National Science Council of Sri Lanka 17(2): 237 - 239.

17. Bandara B.M.R., Jayasinghe L., Karunaratne V., Wannigama G.P., Bokel M., Kraus W. \& Sotheeswaran S. (1989d). Ecdysterone from stem of Diploclisia glaucescens. Phytochemistry 28(4): 1073 - 1075. 
18. Bandara B.M.R., Jayasinghe L., Karunaratne V., Wannigama G.P., Kraus W., Bokel M. \& Sotheeswaran S. (1989e). Diploclisin, a bidesmosidic triterpenoid saponins from Diploclisia glaucescens. Phytochemistry 28: 2783.

19. Bandara B.M.R., Gunatilaka A.A.L., Wijeratne E.M.K. \& MacLeod J.K. (1990a). Acridone alkaloids and coumarins from Pleiospermium alatum. Phytochemistry 29(1): 297 -301 .

20. Bandara B.M.R., Hewage C.M., Jayamanne D.H.L.W., Karunaratne V., Adikaram N.K.B., Pinto M.R.M. \& Wijesundara D.S.A. (1990b). Biological activity of some steam distillates from ten species of Rutaceae plants. Journal of the National Science Council of Sri Lanka 18(1): $71-77$.

21. Bandara B.M.R., Hewage C.M., Karunaratne V., Wannigama G.P. \& Adikaram N.K.B. (1992). An antifungal chromene from Eupatorium riparium. Phytochemistry 31(6): 1983 - 1985.

22. Bandara K.A.N.P., Kumara V., Jacobssonb U. \& Molleyres L.P. (2000). Insecticidal piperidine alkaloid from Microcos paniculata stem bark. Phytochemistry 54: 29-32.

23. Bebernitz G.R. et al. (13 authors)(2001). The Effect of 1,3Diaryl-[1H]-pyrazole-4-acetamides on glucose utilization in ob/ob Mice. Journal of Medicinal Chemistry 44(16): $2601-2611$.

DOI: http://dx.doi.org/10.1021/jm010032c

24. Bokel M., Diyasena M.N.C., Gunatilaka A.A.L., Kraus W. \& Sotheeswaran S. (1988). Canaliculatol, an antifungal resveratrol trimer from Stemonoporous canaliculatus. Phytochemistry 27(2): 377 - 380 .

25. Bombuwala K., Kathirgamanathar S., Thadani V., Jayalal R.G.U., Adikaram N.K., Wijesundara D.S.A., Andersen R.J., Wolseley P. \& Karunaratne V. (2008). Chemistry of Heterodermia mycrophylla, a lichen new to Sri Lanka. Journal of the National Science Foundation of Sri Lanka 36(3): $251-252$.

DOI: http://dx.doi.org/10.4038/jnsfsr.v36i3.163

26. Caldecott J.O., Jenkins M.D., Johnson T. \& Groombridge B. (1994). Priorities for conserving global species richness and endemism. World Conservation Monitoring Center Biodiversity Series No. 3 (eds. N. M. Collins), p. 17. World Conservation Press, Cambridge, UK

27. Casey R.C.D. (1960). Alleged antifertility plants of India. Indian Journal of Medical Sciences 14: 590 - 600.

28. Chandrasena J.P.C. (1935). The Chemistry and Pharmacology of Ceylon and Indian Medicinal Plants. H \& C Press, Colombo.

29. Cordel G. A. (1978). Progress in Phytochemistry. Pergamon, London, UK.

30. Culotta E. \& Koshland D.E. (1993). p53 sweeps through cancer research. Science 262: 1958 - 1961. DOI: http://dx.doi.org/10.1126/science.7903477

31. Dassanayake M.D. (1996). Revised Handbook to the Flora of Ceylon, Oxford \& IBH Publishing Co. Pvt. Ltd., New Delhi, India.

32. De Silva S.S.M., Gamage S.K.T., Kumar N.S. \& Balasubramaniam S. (1982). Anti-bacterial activity of extracts from the brown seaweed Stoechospermum marginatum. Phytochemistry 21(4): 944 - 945.
33. Dhanabalasingham B., Karunaratne V., Gunatilaka A.A.L., Tezuka Y. \& Kikuchi T. (1996). Biogenetically important quinonemethides and other constituents of Salacia reticulata. Phytochemistry 42: 1377.

34. Dharmaratne H.R.W., Wijesinghe W.M.N.M. \& Thevanasem V. (1999). Antimicrobial activity of xanthones from Calophyllum species, against methicillinresistant Staphylococcus aureus (MRSA). Journal of Ethnopharmacology 66(3): 339 - 342.

35. Dharmasiri M.G., Ratnasooriya W.D. \& Thabrew M.I. (2002). Anti-inflammatory activity of decoctions of leaves and stems of anisomeles indica at preflowering and flowering stages. Pharmaceutical Biology 40(6): 433 -439 .

DOI: http://dx.doi.org/10.1076/phbi.40.6.433.8441

36. Dharmasiri M.G., Jayakody J.R.A.C., Galhena G., Liyanage S.S.P. \& Ratnasooriya W. D. (2003). Anti-inflammatory and analgesic activities of mature fresh leaves of Vitex negundo. Journal of Ethnopharmacology 87(2-3): 199 - 206.

37. Feistner G.J. \& Beaman B.L. (1987). Characterization of 2.3-dihydroxybenzoic acid from Nocardia asteroids GUH2. Journal of Bacteriology 169(9): 3982 - 3987.

38. Gunatilaka A.A.L. (1999). The Alkaloids: Chemistry and Biology, pp. 1 - 101. Academic press, New York, USA.

39. Gunatilaka A.A.L., Dhanabalasingham B., Karunaratne V., Kikuchi T. \& Tezuka Y. (1993). Studies on terpenoids and steroids, structure of a d:a-friedo oleananetriterpenoid from Salacia reticulata and revision of the structure of Kokoonol, Kokzeylanol series of triterpenoids. Tetrahedron 45: 10397.

40. Gunatilaka A.A.L., Kingston D.G., Wijeratne E.M., Bandara B.M., Hofmann G.A. \& Johnson R.K. (1994). Biological activity of some coumarins from Sri Lankan Rutaceae. Journal of Natural Products 57(4): 518 - 520. DOI: http://dx.doi.org/10.1021/np50106a013

41. Gunatilleke I.A.U.N. \& Gunatilleke C.V.S. (1990). Distribution of Floristic richness and its distribution and conservation in Sri Lanka. Conservation Biology 4(1): $21-31$. DOI: http://dx.doi.org/10.1111/j.1523-1739.1990.tb00262.x

42. Halici M., Odabasoglu F., Suleyman H., Cakir A., Aslan A. \& Bayir Y. (2005). Effects of water extracts of Usnea longissima on antioxidant enzyme activity and mucosal damage caused by indomethacin in rats. Phytomedicine 12: $656-662$.

DOI: http://dx.doi.org/10.1016/j.phymed.2004.06.021

43. Handunnetti S.M., Kumara R.R., Deraniyagala S.A. \& Ratnasooriya W.D. (2009). Anti-inflammatory activity of Ixora coccinea methanolic leaf extract. Pharmacognosy Research 1(2): 80 - 90.

44. Hewage C.M., Bandara K.A.N.P., Karunaratne V., Bandara B.M.R. \& Wijesundara D.S.A. (1997). Insecticidal activity of some medicinal plants of Sri Lanka. Journal of the National Science Council of Sri Lanka 25(3): 141 - 150. DOI: http://dx.doi.org/10.4038/jnsfsr.v25i3.5028

45. Hewage C.M., Bandara B.M.R., Karunaratne V., Wannigama G.P., Pinto M.R.M. \& Wijesundara D.S.A. (1998). Antibacterial activity of some medicinal plants of Sri Lanka. Journal of the National Science Foundation of 
Sri Lanka 26(1): 27 - 34 .

DOI: http://dx.doi.org/10.4038/jnsfsr.v26i1.3082

46. Iqbal M.C.M., Jayasinghe U.L.B., Herat H.M.T.B., Wijesekara K.B. \& Fujimoto Y. (2004). A fungistatic chromene from Ageratum conyzoides. Phytoparasitica 32(2): $119-126$.

DOI: http://dx.doi.org/10.1007/BF02979776

47. Jayalal U., Wolseley P., Gueidan C., Aptroot A., Wijesundara S. \& Karunaratne V. (2012). Anzia mahaeliyensis and Anzia flavotenuis, two new lichen species from Sri Lanka. The Lichenologist 44(3): $381-389$.

DOI: http://dx.doi.org/10.1017/S0024282911000946

48. Jayasinghe U.L.B., Nadeem M., Rahman A., Choudhary M.I., Ratnayake H.D. \& Amtul Z. (1998). New antibacterial steroidal alkaloids from Sarcococca brevifolia. Natural Product Letters 12(2): $103-109$.

DOI: http://dx.doi.org/10.1080/10575639808048277

49. Jayasinghe L., Kumarihamy B.M.M., Jayarathna K.H.R.N., Udishani N.W.M.G., Bandara B.M.R., Hara N. \& Fujimoto Y. (2003). Antifungal constituents of the stem bark of Bridelia retusa. Phytochemistry 62(4): $637-641$.

50. Jayasinghe U.L., Puvanendran S., Hara N. \& Fujimoto Y. (2004). Stilbene derivatives with antifungal and radical scavenging properties from the stem bark of Artocarpus nobilis. Natural Products Research 18(6): 571 - 574. DOI: http://dx.doi.org/10.1080/14786410310001643867

51. Jayasinghe U.L., Ratnayake R.M., Medawala M.M. \& Fujimoto Y. (2007). Dihydrochalcones with radical scavenging properties from the leaves of Syzygium jambos. Natural Products Research 21(6): 551 - 554. DOI: http://dx.doi.org/10.1080/14786410601132238

52. Jayasinghe L., Amarasinghe N.R., Arundathie B.G., Rupasinghe G., Jayatilake N.H. \& Fujimoto Y. (2012). Antioxidant flavonol glycosides from Elaeocarpus serratus and Filicium decipiens. Natural Products Reseach 26(8): $717-721$.

DOI: http://dx.doi.org/10.1080/14786419.2010.551514

53. Jayaweera D.M.A. (1982). Medicinal Plants of Sri Lanka. National Science Council of Sri Lanka, 47/5, Mailtland Place, Colombo 07.

54. Karunanayake E.H., Welihinda J., Sirimanne S.R. \& Adorai G.S. (1984). Oral hypoglycaemic activity of some medicinal plants of Sri Lanka. Journal of Ethnopharmacology 11(2): $223-231$.

55. Karunaratne V. (2013). Safeguarding the medicinal value of Sri Lankan flora. Journal of the National Science Foundation of Sri Lanka 41(3): 173 - 174.

DOI: http://dx.doi.org/10.4038/jnsfsr.v41i3.6047

56. Karunaratne V., Hoveyda H.R. \& Orvig C. (1992). General method for the synthesis of trishydroxamic acids. Tetrahedron Letters 33(14): 1827 - 1830.

57. Karunaratne V., Bombuwala K., Kathirgamanathar S., Kumar V., Karunaratne D.N., Ranawana K.B., Wijesundara D.S.A., Weerasooriya A. \& De Silva E.D. (2002). An association between the butterfly, Talicada nyseus and the lichen as evidenced from chemical studies. Current Science 83(6): 741 - 745.

58. Karunaratne V., Bombuwala K., Kathirgamanathar S. \&
Thadani V. (2005). Lichens: a chemically important biota. Journal of the National Science Foundation of Sri Lanka 33(3): $169-186$.

DOI: http://dx.doi.org/10.4038/jnsfsr.v33i3.2323

59. Kathirgamanathar S., Williams D.E., Andersen R.J., Bombuwela K., De Silva D. \& Karunaratne V. (2005). Beta-orcinol depsidones from the lichen Usnea sp., from Sri Lanka. Natural Products Research 19(7): 695 - 701. DOI: http://dx.doi.org/10.1080/14786410512331330639

60. Kathirgamanathar S., Ratnasooriya W.D., Baekstrom P., Andersen R.J. \& Karunaratne V. (2006). Chemistry and bioactivity of physciaceae lichens Pyxine consocians and Heterodermia leucomelos. Pharmaceutical Biology (Formerly International Journal of Pharmacognosy) 44(3): $217-220$.

DOI: http://dx.doi.org/10.1080/13880200600686624

61. Keerthi A.A.P., Ekanayake S. \& Premakumara G.A.S. (2009). A new cytotoxic flabelliferin from palmyrah (Borassus flabellifer L.) flour. Journal of the National Science Foundation of Sri Lanka 37(4): 269 - 271.

DOI: http://dx.doi.org/10.4038/jnsfsr.v37i4.1474

62. Kouam S.F., Khan S.N., Krohn K., Ngadjui B.T., Kapche D.G.W.F., Yapna D.B., Zareem S., Moustafa A.M.Y. \& Choudhary M.I. (2006). $\alpha$-Glucosidase inhibitory anthranols, kenganthranols A-C, from stem bark of Harungana madagascariensis. Journal of Natural Products 69: $229-233$.

DOI: http://dx.doi.org/10.1021/np050407n

63. Kumar V., Karunaratne V., Sanath M.R., Meegalle K. \& MacLeod J.K. (1990). Two fungicidal phenylethanones from Euodia lunu-ankenda root bark. Phytochemistry 29(1): $243-245$.

64. Lee S.O., Choi G.J., Jang K.S., Lim H.K., Cho K.Y. \& Kim J.C. (2007). Antifungal activity of five plant essential oils as fumigant against postharvest and soilborne plant pathogenic fungi. Plant Pathology Journal 23(2): 97 - 102.

DOI: http://dx.doi.org/10.5423/PPJ.2007.23.2.097

65. Marles R.J. \& Farnsworth R. (1994). Plants as sources of antidiabetic agents. Economic and Medicinal Plants Research 6: 149 - 187.

66. Melo E.B., Gomes A.S. \& Carvalho I. (2006). $\alpha$ - and $\beta$ Glucosidase inhibitors; chemical structure and biological activity. Tetrahedron 62: 10277 - 10302. DOI: http://dx.doi.org/10.1016/j.tet.2006.08.055

67. Ministry of Environment (MOE) (2012). The National Red List 2012 of Sri Lanka: Conservation Status of the Fauna and Flora (eds. D.K. Weerakoon \& S. Wijesundara), pp. 340 - 345. Ministry of Environment, Colombo.

68. Munasinghe J.T.C., Seneviratne C.K., Thabrew M.I. \& Abeysekera A.M. (2001). Antiradical and antilipoperoxidative effects of some plant extracts used by Sri Lankan traditional medical practitioners for cardioprotection. Phytotherapy Research 15(6): 519 - 523. DOI: http://dx.doi.org/10.1002/ptr.994

69. Nanayakkara C., Bombuwala K., Kathirgamanathar S., Adikaram N.K.B., Wijesundara D.S.A., Hariharan G.H., Wolseley P. \& Karunaratne V. (2005). Effect of some lichen extracts from Sri Lanka on larvae of Aedes aegypti and the fungus Cladosporium cladosporioides. Journal 
of the National Science Foundation of Sri Lanka 33(2): $147-149$.

DOI: http://dx.doi.org/10.4038/jnsfsr.v33i2.2345

70. Neu H.C. (1992). The crisis in antibiotic resistance. Science 257(5073): $1064-1073$.

DOI: http://dx.doi.org/10.1126/science.257.5073.1064

71. Nissanka A.P.K., Karunaratne V., Bandara B.M.R., Kumar V., Nakanishi T., Nishi M., Inada A., Tillekeratne L.M.V., Wijesundara D.S.A. \& Gunatilaka A.A.L. (2001). Antimicrobial alkaloids from Zanthoxylum tetraspermum and caudatum. Phytochemistry 56(8): 857 - 861.

72. Orange A., Wolseley P., Karunaratne V. \& Bombuwela K. (2001). Two leprarioid lichens new to Sri Lanka. Bibliotheca Lichenologica 78: $327-333$.

73. Piers E. \& Karunaratne V. (1983). Conjugate addition of lithiumphenylthioand Cyano-2-(4-chlorobut-1-enyl)cuprate to cyclic enones; an efficient Methylenecylcopentane annulation process. Journal of the Chemical Society, Chemical Communications 17: 935 - 936.

DOI: http://dx.doi.org/10.1039/c39830000935

74. Piyasena K.G. \& Dharmaratne H.R. (2013). Allelopathic activity studies of Mikania scandens. Natural Products Research 27(1): 76 - 79.

DOI: http://dx.doi.org/10.1080/14786419.2012.656110

75. Premakumara G.A.S., Ratnasooriya W.D. \& Tillekeratne L.M.V. (1996). Isolation of a non-steroidal contragestative agent from Sri Lankan marine red alge, Gelidiella acerosa. Contraception 54: 379 - 383.

76. Puvanendran S., Wickramasinghe A., Karunaratne D.N., Carr G., Wijesundara D.S.A., Andersen R.J. \& Karunaratne V. (2008). Antioxidant constituents from Xylopia championii. Pharmaceutical Biology 46(5): 352 - 355. DOI: http://dx.doi.org/10.1080/13880200801887989

77. Raskin P.R., Hollander P.A., Lewin A., Gabbay R.A., Bode B. \& Garber A.J. (2007). Basal insulin or premix analogue therapy in type 2 diabetes patients. European Journal of Internal Medicine 18(1): 56 - 62 .

DOI: http://dx.doi.org/10.1016/j.ejim.2006.09.006

78. Ratnasooriya W.D. \& Dharmasiri M.G. (2001). Antiinflammatory activity of Argyreia populifolia leaf juice. Vidyodaya Journal of Science 10: 99 - 102.

79. Ratnasooriya W.D., Daraniyagala S.A., Galhena G., Liyanage S.S.P., Bathige S.D.N.K. \& Jayakoday J.R.A.C. (2005). Anti-inflammatory activity of the aqueous leaf extract of Ixora coccinea. Pharmaceutical Biology 43(2): $147-152$.

DOI: http://dx.doi.org/10.1080/13880200590919483

80. Ratnasooriya W.D. \& Fernando T.S.P. (2009). Antiinflammatory activity of Sri Lankan black tea (Camellia sinensis L.) in rats. Pharmacognosy Research 1(1): 11 - 20.

81. Ratnayake R., Jayasinghe S., Bandara B.M.R., Andersen R.J. \& Karunaratne V. (2008). Complete 2D NMR assignment and antifungal activity of Ishwarane isolated from Hortonia, a geneus endemic to Sri Lanka. Journal of the National Science Foundation of Sri Lanka 36(1): $109-112$.

DOI: http://dx.doi.org/10.4038/jnsfsr.v36i1.139

82. Ratnayake R., Karunaratne V., Bandara B.M.R., Kumar V., Macleod J.K. \& Simmonds P. (2001). Two new lactones with mosquito larvicidal activity from three Hortonia species. Journal of Natural Products 64(3): 376 - 378.

DOI: http://dx.doi.org/10.1021/np000371t

83. Ristuccia A.M. \& Cunha B.A. (1984). Antimicrobial Therapy. Raven Press, New York, USA.

84. Rozman V., Kalinovic I. \& Korunic Z. (2007). Toxicity of naturally occurring compounds of Lamiaceae and Lauraceae to three stored product insects. Journal of Stored Products Research 43: 349 - 355.

DOI: http://dx.doi.org/10.1016/j.jspr.2006.09.001

85. Saalu L.C., Togun V.A., Oyewopo A.O. \& Raji Y. (2006). Artificial crypptorchidism and the moderating effect of melatonin in Sprague-Dawley rats. Journal of Applied Science 6(12): 2889 - 2894.

86. Saalu L.C., Ajayi G.O., Adeneye A.A., Imosemi I.O. \& Osinubi A.A. (2009a). Ethanolic seed extract of graprfruit (Citrus paradisi) as an effective attenuator of doxorubicininduced oxidative stress in the rat heart. International Journal of Cancer Research 5(2): 44 - 52.

DOI: http://dx.doi.org/10.3923/ijcr.2009.44.52

87. Saalu L.C., Enye L.A. \& Osinubi A.A. (2009b). An assessment of the histomorphometric evidences of doxorubicin-induced testicular cytotoxicity in Wistar rats. International Journal of Medical Sciences 1: 370 - 374.

88. Saalu L.C., Osinubi A.A. \& Olagunju J.A. (2010). Early and delayed effects of doxorubicin on testicular oxidative status and spermatogenesis in rats. International Journal of Cancer Research 6(1): $1-9$.

DOI: http://dx.doi.org/10.3923/ijcr.2010.1.9

89. Sahib K., Kularatne N.S., Kumar S. \& Karunaratne V. (2008). Effect of (+)-usnic acid on the shot-hole borer (Xyleborus fornicatus Eichh.) of tea. Journal of the National Science Foundation of Sri Lanka 36(4): 335 - 336.

DOI: http://dx.doi.org/10.4038/jnsfsr.v36i4.274

90. Sakagami Y., Kajimura K., Wijesinghe W.M. \& Dharmaratne H.R. (2002). Antibacterial activity of calozeyloxanthone isolated from Calophyllum species against vancomycinresistant Enterococci (VRE) and synergism with antibiotics. Planta Medica 68(6): 541 - 543.

DOI: http://dx.doi.org/10.1055/s-2002-32558

91. Sakagami Y., Iinuma M., Piyasena K.G.N.P. \& Dharmaratne H.R.W. (2005). Antibacterial activity of $\alpha$-mangostin against vancomycin resistant Enterococci (VRE) and synergism with antibiotics. Phytomedicine 12(3): $203-208$.

DOI: http://dx.doi.org/10.1016/j.phymed.2003.09.012

92. Simon D. (2010). Epidemiological features of type 2 diabetes. Review Practitioner 60(4): 469 - 473.

93. Somasekaram T., Perera M.P., de Silva M.B.G. \& Godellawatta H. (1997). Arjuna's Atlas of Sri Lanka. Arjuna Consulting Co. Ltd., Dehiwala.

94. Sotheeswaran S., Sultanbawa M.U.S., Surendrakumar S., Balasubramaniam S. \& Bladon P. (1985). Polyphenols from dipterocarp species. vaticaffinol and I [small micro]-viniferin. Journal of the Chemical Society, Perkin Transactions 1: $159-162$.

DOI: http://dx.doi.org/10.1039/p19850000159

95. Tezuka Y., Kikuchi T., Dhanabalasingham B., Karunaratne V. \& Gunatilaka A.A.L. (1993). Salacenonal: a novel nortriterpenoid aldehyde of biogenetic significance from 
Salacia reticulata. Natural Products Letters 3(4): 273 -276 .

DOI: http://dx.doi.org/10.1080/10575639308043876

96. Tezuka Y., Kikuchi K., Dhanabalasingham B., Karunaratne V. \& Gunatilaka A.A.L. (1994). Studies on terpenoids and steroids, part 25. Complete ${ }^{\mathrm{I}} \mathrm{H}$ and ${ }^{13} \mathrm{C}$ NMR assignments of salaciquinone, a new 7-Oxo-Quinonemethide dinortriterpenoid from Salacia reticulata. Journal of Natural Products 57(2): 270 - 276.

DOI: http://dx.doi.org/10.1021/np50104a012

97. Thadani V.M., Khan N.S., Karunaratne V. \& Choudhary M.I. (2011). Alpha-glucosidase inhibitors from lichens. US 7,867,989 B2, U.S. Patent, U.S.A.

98. Thadani V.M., Choudhary M.I., Khan S. \& Karunaratne V. (2012). Antimicrobial and toxicological activities of some depsides and depsidones. Journal of the National Science Foundation of Sri Lanka 40(1): 43 - 48. DOI: http://dx.doi.org/10.4038/jnsfsr.v40i1.4167

99. Tillekeratne L.M., Liyanage G.K., Ratnasooriya W.D., Ksebati M.B. \& Schmitz F.J. (1989). A new spermatostatic glycoside from the soft coral Sinularia crispa. Journal of Natural Products 52(5): 1143 - 1145.

DOI: http://dx.doi.org/10.1021/np50065a038

100. Trimen H. (1885). A Handbook to the Flora of Ceylon, part III, pp. 437 - 463. Dulau \& Co., London, UK.

101. Ware W.G. \& Whitaker M.D. (2004). The Pesticide Book. Thomson Publishers, Fresno, USA.

102. Whitson E.L., Mala S.M.V.D., Veltri C.A., Bugni T.S., de Silva E.D. \& Ireland C.M. (2006). Oppositines A and $\mathrm{B}$, Sesquiterpene pyridine alkaloids from a Sri Lankan Pleurostylia opposita. Journal of Natural Products 69(12): 1833 - 1835.

DOI: http://dx.doi.org/10.1021/np060459s

103. Wijeratne E.M.K., De Silva L.B., Kikuchi T., Tezuka Y., Gunatilaka A.A.L. \& Kingston D.G.I. (1995). Cyathocaline, an azafluorenone alkaloid from Cyathocalyx zeylanica. Journal of Natural Products 58(3): 459 - 462. DOI: http://dx.doi.org/10.1021/np50117a020

104. Wijesundara S., Kathriarachchi H.S., Ranasinghe S.W. \& Hapuarachchi G. (2012). Analysis of seed plants of Sri Lanka. The National Red List 2012 of Sri Lanka: Conservation Status of the Fauna and Flora (eds. D.K. Weerakoon \& S. Wijesundara), pp. 340 - 345. Ministry of Environment, Colombo.

105. Williams D.E., Bombuwala K., Lobkovsky E., de Silva E.D., Karunaratne V., Allen T.M., Clardy J. \& Andersen R.J. (1998). Ambewelamides A and B, antineoplastic epidithiapiperazinediones isolated from the lichen Usnea sp. Tetrahedron Letters 39(52): 9579 - 9582.

106. Williams D.E., Loganzo F., Whitney L., Togias J., Harrison R., Singh M.P., McDonald L.A., Kathirgamanathar S., Karunaratne V. \& Andersen R.J. (2011). Depsides isolated from the Sri Lankan lichen Parmotrema sp. exhibit selective Plk1 inhibitory activity. Pharmaceutical Biology 49(3): $296-301$.

DOI: http://dx.doi.org/10.3109/13880209.2010.517540 